'llu. Revista de Ciencias de las Religiones

ISSN: $1135-4712$

http://dx.doi.org/10.5209/ILUR.61020

\title{
Orfeo en los Infiernos. Imágenes apulias del destino del alma
}

\author{
Paloma Cabrera ${ }^{2}$
}

Recibido: 10 de noviembre de 2017 / Aceptado: 12 de febrero de 2018

Resumen. Un pequeño grupo de vasos apulios de la segunda mitad del siglo IV a.C. representan el descenso de Orfeo a los Infiernos, su llegada ante el palacio de Hades y Perséfone, donde logró con su canto conmover a los dioses infernales. El programa iconográfico de estos vasos, pleno de relatos míticos y de enseñanzas religiosas destinadas a proporcionar consuelo y esperanza de vida más allá de la muerte, nos permite conocer el imaginario del reino subterráneo y a esta figura religiosa que intercede ante los dioses del inframundo para obtener de ellos la salvación de los mortales, su ingreso en un allende beatífico y paradisíaco.

Palabras clave: Orfeo, Infiernos, Plutón, Perséfone, cultos mistéricos, Magna Grecia, iconografía.

\section{[en] Orpheus in the Underworld. Apulian Images of the Soul's Destiny}

\begin{abstract}
A small group of Apulian vases of the second half of the IV century B.C. show the descent of Orpheus to the Underworld, his arrival to Hades' and Persephone's palace, where he was able to thrill both infernal gods with his song. The iconographic program of these vases, full of mythical stories and religious teachings destined to give comfort and hope of life beyond death, allows us to know the imagery of the underworld kingdom and of this religious character that intercedes before the netherworld gods to obtain from them the salvation of the mortals and their entry in a beatifical and paradisiacal world beyond ours.
\end{abstract}

Keywords: Orpheus, Underworld, Hades, Persephone, Mystic Cults, Magna Graecia, iconography.

Sumario. 1. Introducción. 2. El paisaje del Hades. 3. Los habitantes y visitantes del Hades. 4. La catábasis de Orfeo. 5. Conclusiones. 6. Bibliografía.

Cómo citar: Cabrera, P. (2018), Orfeo en los Infiernos. Imágenes apulias del destino del alma, en 'Ilu. Revista de Ciencias de las Religiones 23, 31-55.

\section{Introducción}

Una de las descripciones literarias más vívidas y, a la vez, paradigmáticas del Hades, de su geografía, de los personajes míticos que lo pueblan o transitan por él, y de lo que allí sucede, nos la proporciona un texto apócrifo de Platón, el Axíoco. En este diálogo, Sócrates consuela al moribundo Axíoco argumentando que la muerte no es

\footnotetext{
1 Este trabajo se elaboró en el marco del Proyecto de Investigación "Hombres y dioses. Literatura, religión y filosofía entre oriente y occidente" (FFI2013-43126-P).

2 Museo Arqueológico Nacional (España)

Correo electrónico: paloma.cabrera@cultura.gob.es
} 
temible, sino deseable, y exponiéndole los motivos que permiten creer en la supervivencia del alma y en la felicidad que espera a los hombres en una existencia nueva y transformada. Para ello utiliza el relato mítico del mago Gobrias, quien había leído en unas tablillas de bronce hiperbóreas cómo

"el alma, tras separarse del cuerpo, va hacia un lugar lóbrego, a una morada subterránea, donde está el señorío de Plutón (....). El propileo del camino hacia Plutón está asegurado con cerrojos y llaves de hierro. Cuando se abre, se encuentra el río Aqueronte, y tras él el Cocito, los cuales hay que cruzar para ser llevados ante Minos y Radamanto, en el lugar llamado "llanura de la verdad". Allí están sentados unos jueces que a cada uno de los que llegan piden cuentas acerca de qué vida han llevado y de cuáles han sido sus hábitos mientras habitaban en un cuerpo. Mentir es imposible. Aquellos que durante la vida fueron inspirados por un buen espíritu van a habitar el recinto de los piadosos (...). Por el contrario, los que han dirigido su vida por malas acciones, son llevados por las Erinias al Erebo y al Caos, a través del Tártaro, donde se halla la residencia de los impíos, las tinajas sin fondo de las Danaides, Tántalo torturado por la sed, las entrañas de Ticio comidas y eternamente regeneradas, la piedra interminable de Sísifo, cuyo esfuerzo comienza de nuevo sin fin. Allí, lamidos por fieras salvajes, quemados continuamente por las antorchas de las Venganzas y maltratados por suplicios de toda clase, se consumen en eternas condenas."

No es la del Axíoco la única descripción del Hades, ni la más antigua, pero si una de las primeras en presentar un cuadro sintético de este espacio y en ofrecer, en el reino de los muertos, dos destinos diametralmente opuestos: un recinto para los piadosos, un locus amoenus paradisíaco, y un lugar de castigos, sufrimientos y terror.

De la imagen poética a la imagen pintada, el texto platónico nos conduce a las primeras descripciones pictóricas del Hades y ninguna tan completa, aunque no conservada, como lo fue la Nekyia de Polignoto pintada en la Lesche de los Cnidios ${ }^{4}$. Sin embargo, la pintura de Delfos no suscitó el interés de los pintores de vasos áticos por describir o representar este espacio imaginario en forma de un cuadro holístico que presentara y sintetizara las principales ideas religiosas sobre el destino del alma y la vida tras la muerte en el reino infernal, en ese lóbrego lugar donde reinan Plutón y Perséfone. No fueron los artistas áticos, sino los pintores apulios ${ }^{5}$ de la segunda mitad del siglo IV a.C. quienes lo imaginaron y representaron en sus grandes vasos funerarios, crateras de volutas y ánforas monumentales que acompañaron al difunto en su tumba con un programa iconográfico pleno de relatos míticos y de enseñanzas religiosas destinadas, como el relato de Sócrates en el Axíoco platónico, a proporcionar consuelo y esperanza de vida más allá de la muerte.

El Sur de Italia era el ámbito propicio para desarrollar en imágenes esta teología del Más Allá, pues en ningún otro lugar arraigaron y se desarrollaron con tanta fuerza determinadas religiones mistéricas -cultos dionisíacos, eleusinos, órficos o pita-

\footnotetext{
Pl. [Ax.] 371a-372a. Traducción de Juan Zaragoza y Pilar Gómez Cardó.

4 Cfr. la descripción de Pausanias 10.28-31, de la Nekyia pintada en la Lesche de Delfos; Stansbury-O'Donnell 1990.

5 Sobre la dependencia o no de las representaciones del Hades apulias respecto a la pintura de Polignoto, cfr. Pensa 1977, 61s.
} 
góricos- que ponían el acento en la fe en la existencia de un destino ultraterreno, eterno y beatífico, para los iniciados en los misterios, quienes, a través de vínculos establecidos en vida con los dioses, obtenían la salvación individual, la liberación final de la negación de la existencia.

Entre la amplísima producción vascular apulia, especialmente la monumental, un pequeño grupo de vasos representan escenas infernales, imágenes del Hades, del reino subterráneo presidido normalmente por el palacio de los dioses infernales, Plutón y Perséfone, todo un microcosmos de alto contenido simbólico y escatológico. El motivo suele ser la catábasis de un héroe o un dios, el descenso a los Infiernos de Dioniso, Heracles, Orfeo, Protesilao/Amfiarao ${ }^{6}$, Teseo, o Adonis ${ }^{7}$. Más allá del relato mítico y del motivo que provoca la catábasis, las imágenes ofrecen una singular combinación de personajes y acciones que condensan toda una doctrina religiosa sobre la vida en el Más Allá, sobre la justicia y el orden cósmico regido y sancionado por los dioses y sobre la posibilidad de obtener la recompensa de una vida beatífica e inmortal para aquellos iniciados en los ritos y misterios salvíficos ${ }^{8}$.

Y de entre todos los personajes míticos que realizan esta catábasis infernal ninguno como el poeta tracio Orfeo ha suscitado mayores controversias entre los investigadores para afirmar o negar la vinculación de sus imágenes con las doctrinas y prácticas religiosas determinadas ${ }^{9}$, para aceptar o rechazar su utilización como fuente de conocimiento de aquel complejo conjunto de nociones míticas y religiosas heterogéneas que se agrupan bajo el concepto bastante vago y amplio de "orfismo"10.

No son muy numerosas las imágenes de la catábasis de Orfeo, una docena de vasos $^{11}$ muestran el paisaje del reino de ultratumba y al poeta tracio llegando ante los dioses infernales. Se trata de las crateras de volutas de Karlsruhe ${ }^{12}$, Nápoles ${ }^{13}, \mathrm{Mu}-$ nich $^{14}$ (Fig. 1), Malibú ${ }^{15}$, Kiel $^{16}$, Bari ${ }^{17}$, Armento ${ }^{18}$ y de la colección Fenicia ${ }^{19}$ (Fig. 2),

6 Existe controversia sobre si se trata de Protesilao, a quien se le concedió volver a la vida por un periodo de tiempo, o Amfiarao, el adivino acogido por Hades. Cfr. Moret 1993, 327-335 y, en contra, Schmidt 2000, 91 s. Moret 1993.

8 Olmos 2008a, 166-171.

9 La historia de las diferentes interpretaciones de las imágenes apulias de los Infiernos fue recogida por M. Pensa, 1977, 1-21; Cfr. también M. Schmidt 1975 y 1991.

10 Schmidt 1975, 106.

11 M.X. Garezou: "Orpheus”, en Lexicon Iconographicum Mythologiae Classicae vol. VII, 1994, 81-105 ha recogido todos los vasos que aquí analizaremos. A partir de ahora citaremos esta obra como "LIMC", seguido del número de la pieza en dicho artículo.

12 Del Pintor de Licurgo o de Darío: LIMC 72; Trendall y Cambitoglou 1978, RVAp I, pl. 160, 1; Moret 1993, ${ }^{\circ}$ 7; Aellen 1994, $\mathrm{n}^{\circ} 28$.

13 Del Pintor de Licurgo o de Darío: LIMC 73; Trendall y Cambitoglou 1978, RVAp I, pl. 160, 2; Moret 1993, nº; Aellen 1994, $\mathrm{n}^{\circ} 2$.

14 Del Pintor de los Infiernos: LIMC 74; Trendall y Cambitoglou 1982, RVAp II, pl. 194; Moret 1993, n 17; Aellen 1994, n 50; Olmos 2008a, 169, fig. 20 (detalle).

15 Del Pintor del Sakós Blanco: LIMC 75; Trendall y Cambitoglou 1982, RVAp II, pl. 323, 3-4; Moret 1993, nº 37; Schauenburg 1984, pl. 94, 1.

16 Del Pintor del Sakós Blanco: LIMC 76; Trendall y Cambitoglou 1991-92, RVAp Suppl. II, p. 351; Moret 1993, $\mathrm{n}^{\circ} 38$; Schauenburg 1984, pl. 100, 1 .

17 LIMC 77; Trendall y Cambitoglou 1991-92, RVAp Suppl. II, p. 351; Moret 1993, nº 39; Schauenburg 1984, tf. $113,1$.

18 Del Pintor de los Infiernos: LIMC 80; Trendall y Cambitoglou 1991-92, RVAp II, pl. 196; Moret 1993, nº 18; Schauenburg 1958, fig. 10; Aellen 1994, nº 78 .

19 LIMC 83; Moret 1993, no 9; Aellen 1994, no 6. 


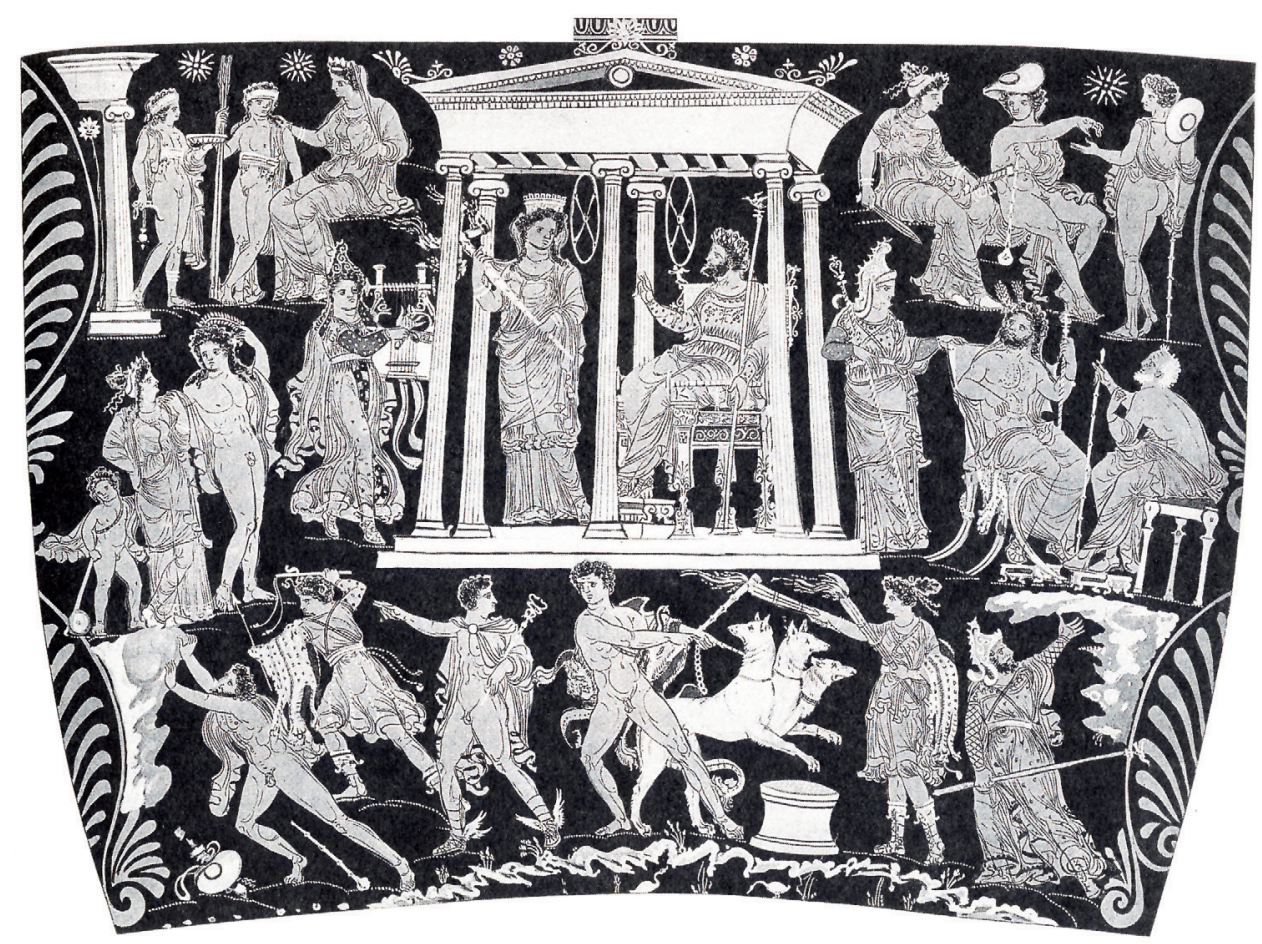

Figura 1. Cratera de volutas de Munich (Schmidt 2000, Abb. 1).

y las ánforas de Tarento $^{20}$, San Petesburgo ${ }^{21}$ y Madrid ${ }^{22}$ (Fig. 3). A estos vasos hay que añadir un fragmento de una cratera de cáliz de Tarento ${ }^{23}$. La cratera de cáliz del Museo Británico, recogida por otros autores en el repertorio de imágenes de Orfeo en los Infiernos, debe ser desechada tras los recientes análisis efectuados que demuestran la falsificación de la escena realizada por el famoso restaurador Gargiulo a comienzos del siglo XVIII ${ }^{24}$. Y el ánfora del Pintor de Perrone ${ }^{25}$ incluida también por algunos en este conjunto, debe ser leída como Orfeo ante los tracios y no como su

20 Asociado al Pintor de la Patera: LIMC 78; Trendall y Cambitoglou 1982, RVAp II, pl. 284, 1; Moret $1993, \mathrm{n}^{\circ} 22$.

21 Del Pintor de la Patera: LIMC 79; Trendall y Cambitoglou 1982, RVAp II, 23/46; Moret 1993, n 21

22 Del Pintor de Baltimore: Museo Arqueológico Nacional, $n^{\circ}$ 2015/97/1; publicada cuando pertenecía a una colección particular de Ginebra: Trendall y Cambitoglou 1991-92, RVAp Suppl. II, 27/40; Moret 1993, fig. 9 a-d, $\mathrm{n}^{\circ} 40$.

23 Trendall y Cambitoglou 1978, RVAp I, p. 41, nº 26; Schauenburg 1984, tf. 109, 1.

24 Villing 2014. El restaurador transformó el perro conducido con una correa por un joven con lira en un perro de tres cabezas, en Cerbero, y los investigadores interpretaron esta figura como Orfeo en los Infiernos. Realizada la limpieza de la antigua falsificación, hoy se interpreta la escena como Anfión y Zetes manteniendo la polémica sobre la música, inspirada por la Antiope de Eurípides.

25 Trendall y Cambitoglou 1978, RVAp I, pl. 190; Pensa 1977, 51; Moret 1993, 322; Garezou 1994, LIMC 21. Todos identifican al personaje sentado en un trono junto a Orfeo y rodeado por guerreros orientales como Hades, pero ningún otro elemento nos permite situarnos en los Infiernos. Creo que se trata de una imagen que sintetiza dos momentos diferentes: Orfeo ante los tracios y Orfeo ante Plutón, como indicación del poder del poeta a través de aquellos que fueron subyugados por sus cantos y su música. Pero no es un cuadro de los Infiernos, por lo que no la incluimos en nuestro estudio. 


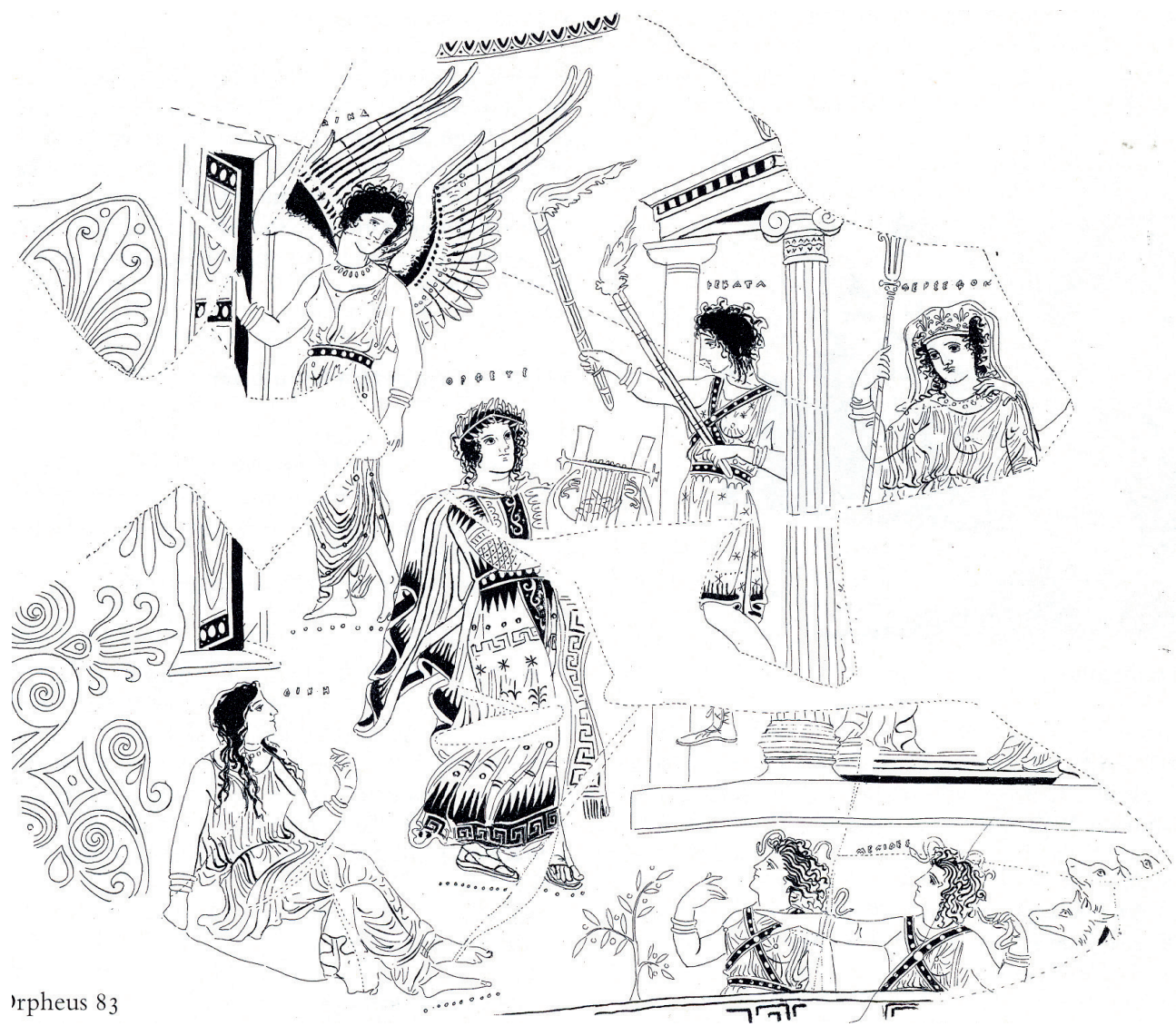

Figura 2. Fragmento de la Colección Fenicia (LIMC VII, 1994, s.v. “Orpheus”, nº 83).

visita a los Infiernos. La presentación, y composición de la escena ${ }^{26}$, varía de las grandes crateras de volutas, donde los personajes se sitúan en varios planos y alturas rodeando el palacio de Hades, a las ánforas cuyas imágenes se estructuran en dos frisos y que, por tanto, solo permiten un desarrollo lineal donde se limita el número de personajes y de elementos "paisajísticos" o constructivos. Los diferentes elementos compositivos y narrativos se estructuran de muy diferente forma en cada uno de estos vasos.

\section{El paisaje del Hades}

Los elementos que definen el paisaje del Hades, que nos permiten situarnos en un espacio determinado, el del reino infernal, son, como es propio de la imaginería griega, escasos, sintéticos, simbólicos y alusivos. Este paisaje no se construye solo con elementos arquitectónicos o naturales -edificios, plantas, rocas, etc.-, sino, sobre todo, con personajes cuyo espacio es indefectible y obligatoriamente el Ha-

26 Schmidt 1991, 36-38; Schmidt 2000, 86-87. 


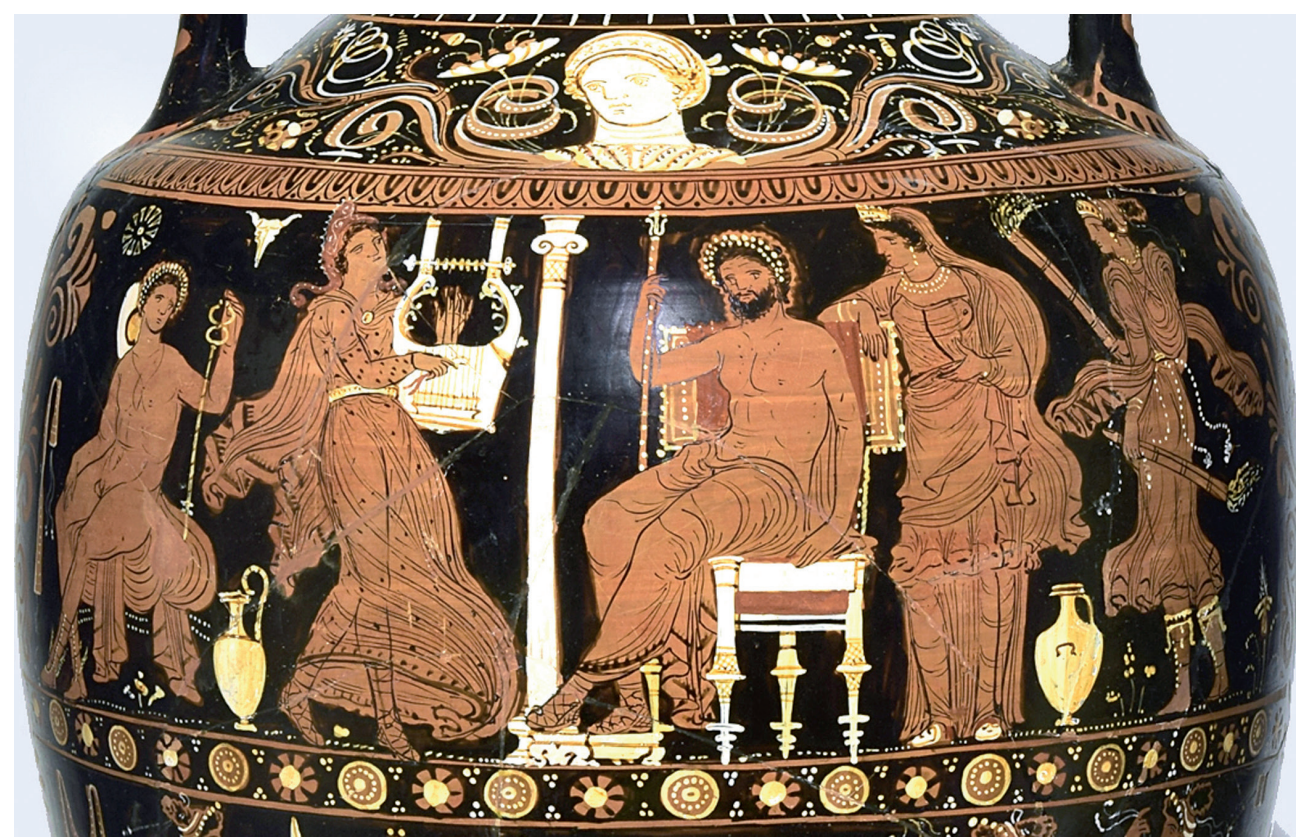

Figura 3. Ánfora del Museo Arqueológico Nacional, Madrid, nº 2015/97/1.

des. El marco espacial está, por tanto, siempre condicionado y referido por el relato mítico.

El principal elemento paisajístico es el palacio infernal, la morada de Plutón y Perséfone $^{27}$. Preside la escena con su gran tamaño, en posición central, rodeado por todos los demás elementos y personajes que dibujan al Hades. Está concebido como un naisco, como un templete, pintado siempre en blanco, elevado sobre una simple plataforma, cubierto por un tejado a dos aguas rematado en un frontón triangular, sostenido por cuatro columnas jónicas o por dos columnas y dos cariátides surgiendo de un cáliz floral, como en la cratera de Nápoles, o por dos columnas jónicas rematadas por sendas figuras de esfinges, como en la cratera de Karlsruhe. En las ánforas, debido a la limitación impuesta por la composición en frisos, no se representa el edificio o se sintetiza en un único y breve elemento, como en el vaso de Madrid, donde una columna jónica blanca marca el límite espacial de la morada subterránea. Este edificio alberga en su interior las figuras de los dioses, Plutón y Perséfone, a veces sentados compartiendo un único lecho $^{28}$, o sentado uno de ellos en un trono y el otro de pie a su lado. El único personaje que ocasionalmente comparte con ellos este espacio es Hécate en las crateras de Karlsruhe y Fenicia.

Entre los elementos arquitectónicos, además del palacio infernal, el más significativo es la puerta del Hades, representada en el fragmento de la colección Fenicia en lo alto de la escena, a la izquierda del palacio. Una puerta que entreabre - o cierraun personaje alado, Nike (fig. 2). No sabemos cuál es la acción concreta ni el signi-

27 LIMC 72-77. Solo en la cratera de volutas de Armento (LIMC 80) no se ha representado el palacio, sino a Perséfone sentada en su trono, elemento que también marca una espacialidad.

28 LIMC 75-77. 
ficado exacto de esta puerta: ¿es frontera para los vivos? ¿una indicación del camino de retorno para aquellos privilegiados que penetraron vivos en el Hades y vivos salen de él? ¿es una puerta que se abre para los piadosos a otro espacio, un camino para acceder a un lugar mejor? ${ }^{29}$. Precisamente Nike, la Victoria, podría ofrecer este premio a héroes y bienaventurados: el triunfo sobre la muerte y el retorno a la vida. Cualquiera de estas lecturas, ninguna de ellas excluyente, podía ser realizada por quien con esta imagen se enterró.

En la cratera de Munich figura parte de otro edificio, posiblemente una fuente situada en una palestra, señalada con una columna jónica que sostiene un arquitrabe, y en cuyo interior figura una pequeña cabeza de león de la que mana agua, representada junto al grupo de los Heráclidas y Megara (fig. 7). Un luterio aparece también en el ánfora de San Petesburgo, junto a una figura femenina - ¿alusión, quizás, al ritual lustral que acompaña a las necesarias nupcias con Hades?- y un ara circular en la cratera de Munich, junto a Heracles y Cerbero (fig. 4).

Los elementos paisajísticos naturales no son ni frecuentes ni explícitos. Una línea sinuosa en las crateras de Karlsruhe, Nápoles y Munich, situada en la zona inferior de la escena, siempre debajo de Heracles y Cerbero, puede marcar un curso de agua, quizás uno de los ríos del inframundo, el Cocito o el Aqueronte, o la Estigia. Líneas de puntos y pilas de rocas marcan el relieve accidentado donde se sientan algunos grupos de personajes en torno al palacio, como el de los Heráclidas en las crateras de Malibú y Kiel, Teseo y Piritoo en la cratera de Karlsruhe, o las Danaides en las crateras de Kiel y Bari. En el caso de los condenados, la presencia de elementos paisajísticos es imprescindible para explicitar su condena: así, en la cratera de Kiel, un manantial brota de una roca sinuosa y llena una de las hidrias con las que las Danaides deberán rellenar la tinaja sin fondo; en la cratera de Munich, Sísifo empuja su roca por una abreviada colina sinuosa (fig. 8) y Tántalo dirige su mano hacia lo alto, hacia una sintética representación de una roca colgante, siempre a punto de caer, siempre en eterno equilibrio. Plantas y flores brotan esporádicamente a los pies de algunos personajes, pero no dibujan un entorno florido y fecundo ni parecen aludir, como en otras imágenes apulias ${ }^{30}$, a la exuberante fertilidad del jardín paradisíaco prometido a los bienaventurados, sino que hacen referencia a un espacio abierto, aunque sea subterráneo.

El Hades se dibuja así en los vasos como un espacio en el que hay que penetrar, guardado por una puerta, como aquel "propíleo ... asegurado con cerrojos y llaves de hierro" del relato platónico, que solo puede abrir o cerrar un demon infernal. Corrientes de agua marcan también, al igual que la puerta, una frontera simbólica, un límite que hay que traspasar para llegar al lugar central de este reino subterráneo: la morada infernal, el suntuoso palacio de Plutón y Perséfone. En las imágenes apulias se dibuja al mismo tiempo y de manera sintética, alrededor del palacio de los dioses de ultratumba, entornos diferentes ${ }^{31}$ : por un lado, el recinto de los piadosos, si podemos entender así como alusión a ese espacio paradisíaco al grupo de los Heráclidas y la fuente de la palestra, lugar de esparcimiento y ejercicio ${ }^{32}$-como indican aríbalo

\footnotetext{
Esta última es la interpretación que realiza Bernabé $(2009,99)$ del fragmento Fenicia.

Cfr. Cabrera 1998.

31 No queremos insinuar que las imágenes apulias ilustren el relato platónico, ni que se inspiran en él. Sencillamente utilizamos el texto para dar palabras a las imágenes, pues las ideas y los símbolos son comunes. Otros relatos nos podrían haber ayudado en esta tarea, y también nos serviremos de ellos.

32 La idea de un ámbito paradisíaco donde los bienaventurados realizan ejercicios atléticos ya fue recogida por Píndaro: “(...) unos se regocijan con caballos y ejercicios gimnásticos, (...) y entre ellos florece abundante la
} 


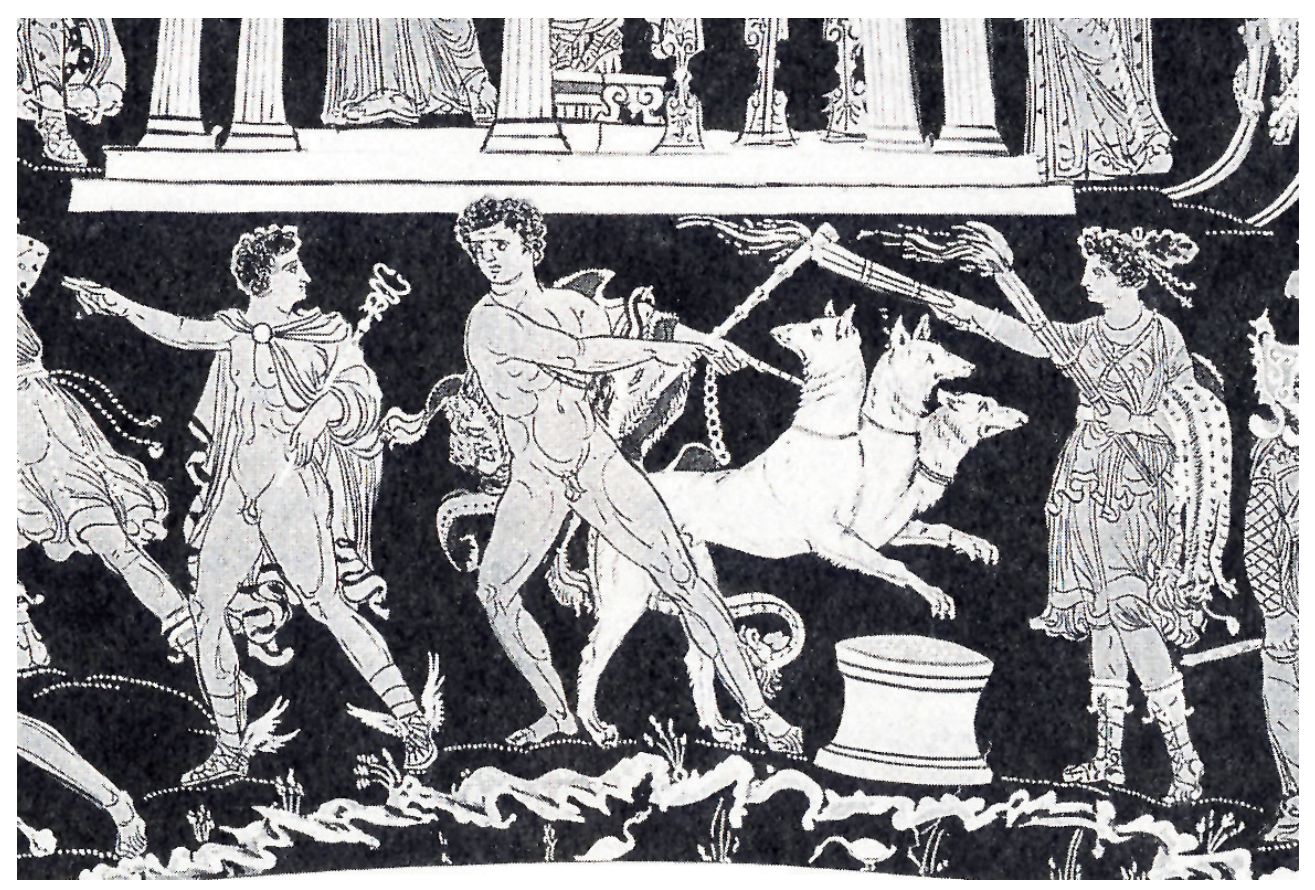

Figura 4. Hermes, Heracles y Hécate en la cratera de Munich (Schmidt 2000, Abb. 1).

y estrígile en manos de uno de ellos- para estos jóvenes inocentes, muertos prematuramente; por otro lado, la morada de los impíos, los abruptos y rocosos paisajes donde los condenados cumplen su castigo. Y un espacio, que en el Axíoco se diferencia de los anteriores y recibe el nombre de "llanura de la verdad", donde los jueces del inframundo juzgan a las almas y deciden su destino, aludido por la presencia de estos personajes en las crateras de Nápoles y Munich (fig. 6).

\section{Los habitantes y visitantes del Hades}

Orfeo es el visitante privilegiado de los Infiernos, pero es algo más que un mero aventurero o héroe temerario que regresa con vida de donde nadie retorna. Es, junto con Plutón y Perséfone, la figura principal de estas imágenes del Inframundo. El poeta tracio, vestido a la manera oriental, con larga túnica bordada, manto anudado al cuello y desplegado hacia atrás como impulsado por el viento, tocado en ocasiones con gorro frigio, tañe las cuerdas de una cítara de altos brazos, pintada en blanco. A veces se sitúa a la izquierda del palacio infernal, en las crateras de Karlsruhe, Nápoles y Munich, a veces a la derecha, en las crateras de Malibú, Kiel y Bari. En los tres primeros vasos, Orfeo todavía está tañendo con el plectro las cuerdas de la cítara, y su vestido se agita con el movimiento y arremolina hacia atrás, sobre los pies que apenas apoyan la punta de los dedos en el suelo. Orfeo está danzando y cantando al mismo tiempo, acompañado por los sones mágicos de su instrumento y agita su cuer- 
po en consonancia con el entusiasmo del canto. En los otros tres vasos, el poeta ha finalizado su canto y su danza, se mantiene estático, en posición frontal, su mirada se dirige a los dioses infernales y la mano que sostiene el plectro descansa hacia abajo, junto a su costado ${ }^{33}$. Orfeo espera atento, expectante, el resultado de su canto.

Plutón y Perséfone, especialmente el primero, son figuras indispensables en este imaginario del Hades. Ellos representan el universo divino que rige los destinos ultraterrenos de los mortales y sintetizan con su sola figura el espacio, la geografía y la teología del Más Allá, del reino de los muertos. La pareja atiende la llegada de Orfeo, ambos escuchan ensimismados el canto y la música seductores del poeta tracio, la mirada fija en su figura. Perséfone se representa normalmente con el cetro rematado en aspa en la mano, excepto en la cratera de Armento, en el fragmento de la colección Fenicia y en el ánfora de Madrid. Siempre está acompañada por Plutón, aunque éste aparece sin su esposa en el ánfora de San Petesburgo, donde el dios es quien acoge a Orfeo, resumiendo en la figura masculina a la pareja divina.

Situada junto a los dioses del Inframundo, dentro del palacio ${ }^{34}$ o junto a él ${ }^{35}$, Hécate, representada de forma similar a las Erinias, con chitón corto, endrómides y en ocasiones piel de animal al brazo, pero sin alas ni serpientes en los cabellos o brazos, a veces acompañada por una pantera ${ }^{36}$, ilumina con sus antorchas las tinieblas del Hades y guía a los que se adentran en este tenebroso espacio. Pero a los que guía no son simples y comunes mortales, sino aquellos personajes excepcionales que han penetrado vivos en el reino infernal y que, por ello, no permanecerán allí definitivamente: Orfeo, Adonis ${ }^{37}$ o Protesila ${ }^{38}$. Solo en la cratera de Munich y en el ánfora de Tarento está situada en otro plano, atenta a Heracles y Cerbero, indicando que vigila el desarrollo normativo de los acontecimientos, que Heracles pueda sacar al perro de tres cabezas de los Infiernos, como había estipulado el pacto entre Hades y el héroe. Ella, por tanto, está presente y cumple su función siempre que dos mundos normalmente incompatibles se ponen en relación o cuando se produce el desplazamiento de un personaje. Su papel como diosa de los Infiernos es fundamental pues, al igual que Hermes, pone en comunicación dos ámbitos existenciales radicalmente alejados y distintos, guía a determinados visitantes, vigila las puertas infernales ${ }^{39}$, y decide, en consecuencia, quién entra y quién sale.

Hermes es su equivalente masculino en esta función de guía, de conductor y de dios de los tránsitos existenciales. En las imágenes de los Infiernos muchas veces rima con su figura la de Hécate. En el ánfora de Madrid ambos se disponen simétricamente a un lado y a otro del grupo central con Orfeo, Hades y Perséfone. Pero si ella está siempre junto al palacio o en su interior, Hermes se sitúa más bien en la frontera, en el espacio limítrofe, iniciando ya con raudo paso su vuelta, y la del héroe al que guía, hacia el mundo de los vivos. Así sucede en las crateras de Karlsruhe, Nápoles y Munich (Fig. 4), donde el motivo parece idéntico, y en el ánfora de Taren-

\footnotetext{
Esta diferencia de postura ya era señalada por Heurgon 1932, 22.

En las crateras de Karlsruhe (LIMC 72) y de la colección Fenicia (LIMC 83).

En las crateras de Malibú (LIMC 75), Kiel (LIMC 76), Bari (LIMC 77) y Armento (LIMC 80) y en las ánforas de Tarento (LIMC 78) y Madrid.

36 En la cratera de Armento (LIMC 80).

37 Aellen 1994, n 54.

38 Aellen 1994, $\mathrm{n}^{\circ} 59,79,80$.

39 Aellen 1994, 59, n 18. En el Himno Órfico (Hymn. Orph. I, 3-8), se la denomina "sepulcral, que se agita delirante entre las almas de los muertos" y "dueña guardiana de todo el universo; conductora".
} 
to: situado a la izquierda de Heracles y Cerbero, dirige su mirada hacia el héroe mientras inicia la marcha en sentido contrario señalando el camino que el héroe debe seguir, instándole a abandonar ya el Hades. Cuando el motivo de Heracles y Cerbero no figura y es el grupo de las Danaides el que ocupa su lugar, Hermes aparece sentado en una roca, alejado de ellas, pues nunca abandonarán el Hades, pero, como ellas, con una hidria o una enócoe en la mano. ¿A qué alude la hidria en manos del dios? Es difícil dar una respuesta, pero puede sugerir una conexión con las Danaides: la hidria es el vaso característico del ritual nupcial, el que contiene el agua del baño purificatorio de la novia; es también un vaso característico de los ajuares funerarios femeninos, de las mujeres que celebrarán sus bodas con Hades, dios de los Infiernos, una vez traspasada la frontera de la muerte. El vaso en las manos del dios en este caso sería un recurso utilizado por el pintor para recordar a quien contempla la escena que, como veremos más adelante, la boda de las Danaides, su matrimonio con los hijos de Egipto, fue bruscamente cercenado por el asesinato, por lo que son merecedoras de una condena eterna.

Otras divinidades y démones pueblan el inframundo. Actúan como asistentes de los dioses infernales y como garantes de la aplicación de sus designios. Así, las Furias o Erinias, representadas con chitón corto, a veces con piel de animal, con serpientes en los cabellos y los brazos, a veces provistas de alas, como en la cratera de Karlsruhe, o con un látigo en la mano, como en las crateras de Munich y Kralsruhe, con el que infligen su castigo a los condenados o vigilan para que se cumpla el destino sancionado por los dioses. En ocasiones su actitud es de reposo, centradas en una distendida conversación, como en la cratera de Kralsruhe, en otras es violenta y agitada, como en la cratera de Munich (Fig. 8), donde una Furia azota sin piedad a Sísifo mientras empuja su interminable roca, y en ocasiones ellas también se han dejado seducir maravilladas por la música de Orfeo: en la cratera de la colección Fenicia (Fig. 2), situadas bajo el palacio de Plutón y Perséfone, delante de Cerbero y Heracles, levantan sus cabezas y vuelven su mirada hacia el mítico cantor, y así, transformadas y apaciguadas por sus cantos, se han convertido en Euménides, como reza la inscripción que las nombra. Las Erinias son figuras indispensables en esta puesta en escena del mundo infernal, pues ejecutan los castigos impuestos a los condenados, mantienen el orden y, por tanto, son instrumento de la justicia divina, cósmica, que castiga a los impíos y premia a los piadosos.

De hecho, Dike, la Justicia, es otro de los protagonistas de las escenas de los Infiernos, y su presencia es esencial. En dos ocasiones está situada en lo alto de la escena, a la derecha, sentada junto a Teseo y Piritoo en la cratera de Munich (Fig. 5), y junto a un Piritoo sentado en el asiento del que nunca se volverá a levantar y con las manos atadas a la espalda, en la cratera de Armento. En ambas ocasiones Dike sostiene una espada en la mano ${ }^{40}$, símbolo de su carácter implacable. En la cratera de la colección Fenicia Dike está situada junto a Orfeo, sentada bajo la puerta del Hades que entreabre $\mathrm{Nike}^{41}$, ensimismada con el canto del poeta, no lleva ningún atributo,

40 En otras escenas infernales en la que se narra la catábasis de Protesilao también aparece Dike: Pensa 1977, tav. XIV a.

41 Esta figura está identificada con la inscripción ]AIKA, precedida de una letra de lectura dudosa: algunos (Harrison 1909,411$)$ la han leído como EURY]DIKA, pero esta teoría no ha sido generalmente aceptada, pues con más seguridad parece tratarse de ]NIKA, es decir, de la Victoria. Para las diversas interpretaciones, cfr. Aellen 1994, 64, n. 57. 


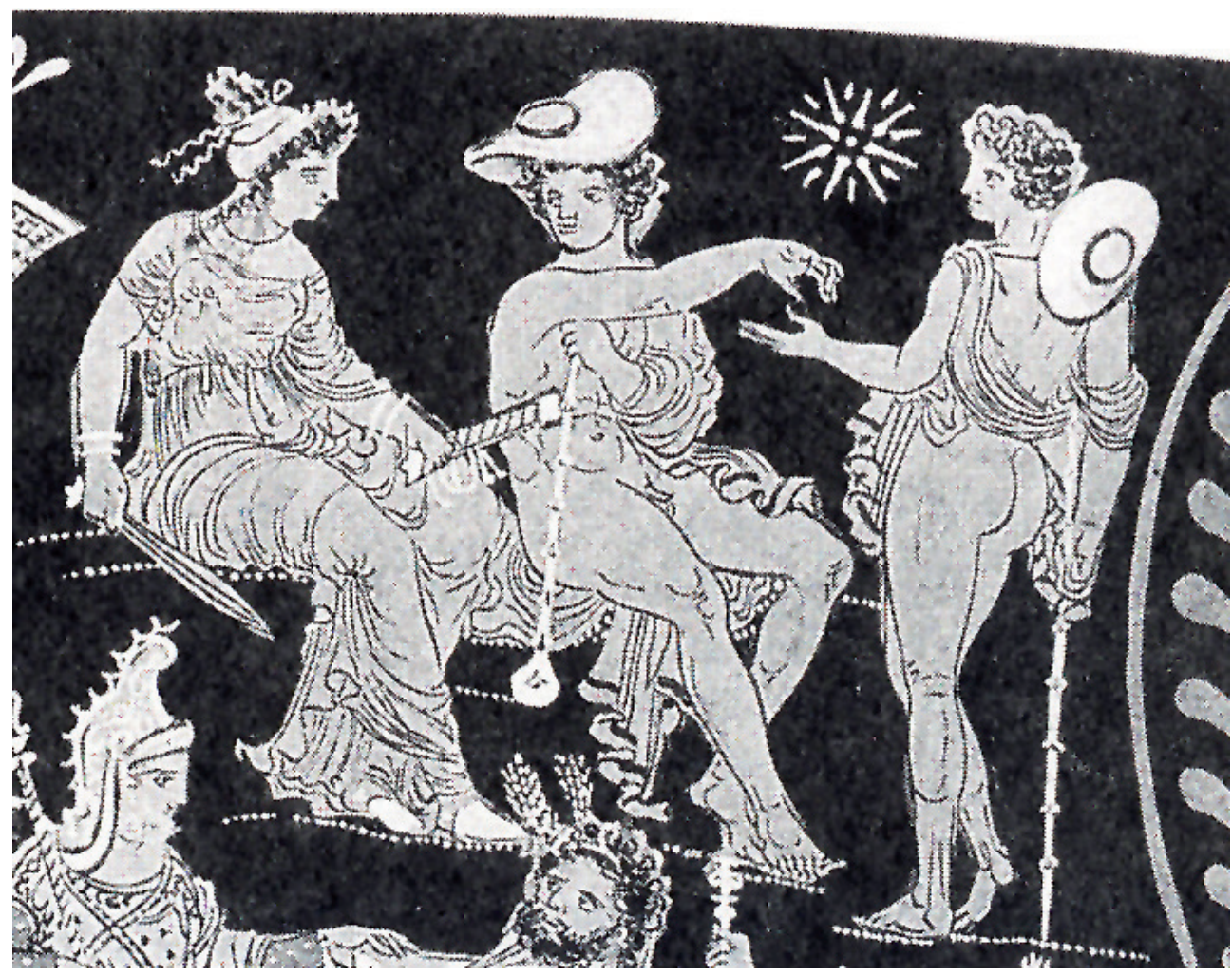

Figura 5. Dike, Teseo y Piritoo en la cratera de Munich (Schmidt 2000, Abb. 1).

ni la espada, y solo es reconocible por la inscripción pintada sobre su cabeza ${ }^{42}$. En este vaso el protagonista no es realmente Orfeo, sino su canto transformador, que ha afectado a todos los que le escuchan: a las Erinias, convertidas en Euménides -como reza la inscripción sobre sus cabezas-, a Hécate y Perséfone, a Nike, que está más atenta al poeta que a su función de guardiana de la puerta del Hades, y a Dike, que por un momento ha olvidado ejercer su poder y se ha desprendido de su espada, incluso a Cerbero, echado en el suelo, cuyas tres cabezas dejan de mirar a Heracles para dirigirse hacia Orfeo. El sonido de la lira ha actuado mágicamente, domando a los espíritus infernales. El canto del poeta ha logrado abrir las puertas y paralizar los Infiernos ${ }^{43}$.

Las Furias y Dike, como ejecutoras de la justicia y vigilantes del cumplimiento de los castigos impuestos, son figuras que encarnan un concepto trascendental ${ }^{44}$ : el orden cósmico regido y sancionado por los dioses que regula el equilibrio entre el

42 La inscripción no está completa, solo se conserva [IKH], y así Pensa 1977, 25, ha leído el nombre de Euridice, pero no hay espacio suficiente para desarrollar el nombre completo.

43 Los poetas posteriores rivalizarán en imaginación para describir los efectos de esta música divina: la rueda de Ixión deja de girar; la roca de Sísifo queda en equilibrio; Tántalo olvida su hambre y su sed, etc. Hasta las mismas Danaides dejan de llenar su tinaja sin fondo. Hades y Perséfone acceden a restituir a Euridice a su marido. Cfr. Virgilio (Verg. G. IV, 453 ss.), Ovidio, (Ov. Met. X, 40 ss.) y Horacio (Hor. Carm. II 13, 33 ss.).

$44 \quad$ Aellen 1994, 58-66. 


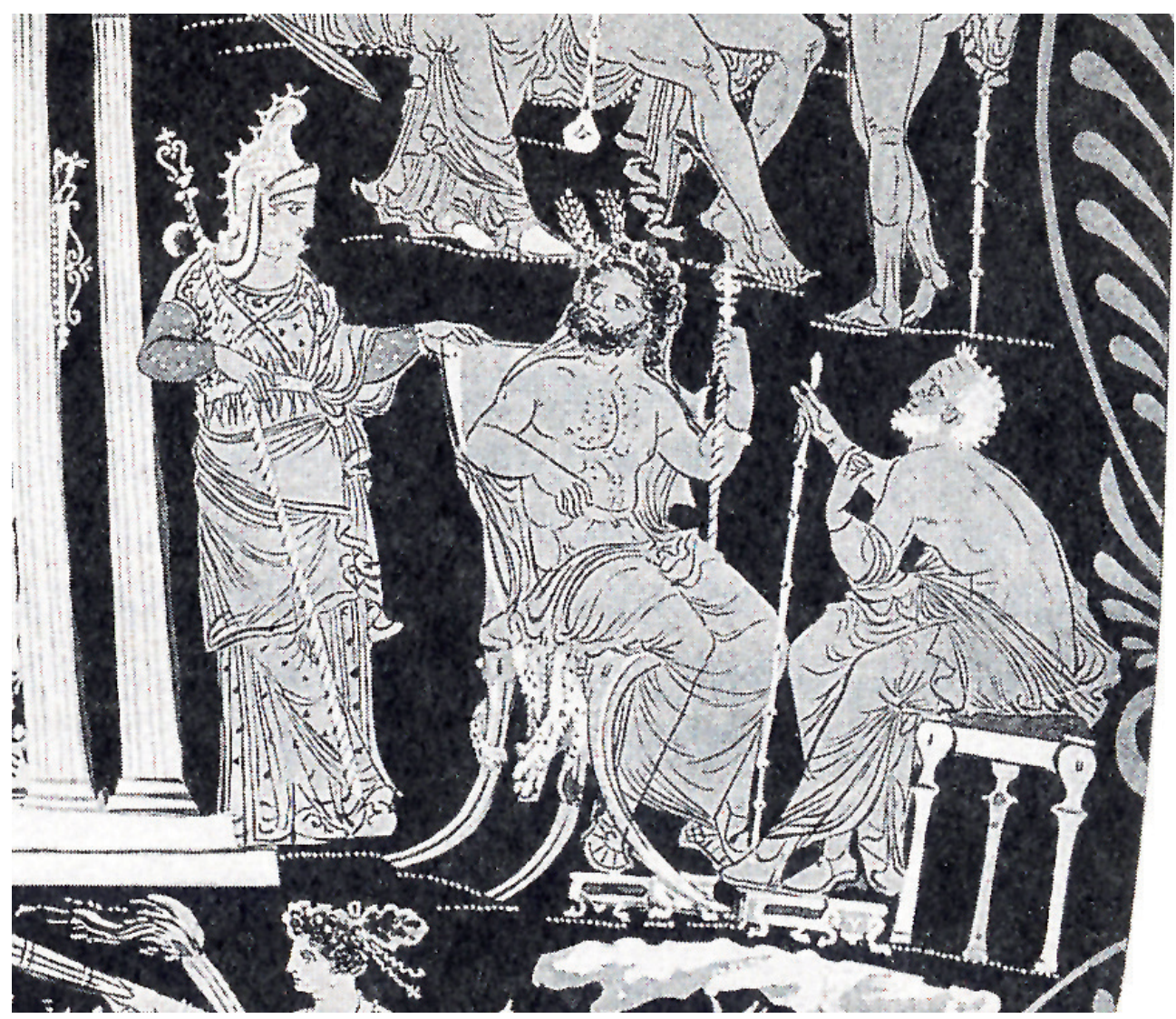

Figura 6. Los Jueces infernales en la cratera de Munich (Schmidt 2000, Abb. 1).

bien y el mal, que premia y castiga, y que ofrece la esperanza de una vida equitativa tras la muerte. A través de ellas los pintores ponen el acento en un Hades donde reina la justicia y donde se puede hallar la salvación.

Un papel trascendental cumplen también tres figuras representadas en las crateras de Nápoles y Munich (Fig. 6): los Jueces infernales, Éaco, Triptolemo y Radamantis, nombrados por inscripciones en el segundo vaso. Situados en un registro medio, junto al palacio de Plutón y Perséfone, en el mismo nivel que Orfeo pero en el lado opuesto, figuran caracterizados como varones maduros, incluso ancianos, sentados o de pie, provistos de cetros de autoridad y parecen dialogar entre ellos, sopesando y debatiendo sus decisiones, asumiendo las funciones otorgadas por Zeus, de forma similar a como las recoge Platón en Gorgias $524 \mathrm{a}^{45}$. Ellos juzgarán a las almas y decidirán su destino: hacia el paraíso beatífico de los bienaventurados, o hacia el

45 "Yo ya había advertido esto antes que vosotros y nombré jueces a hijos míos, dos de Asia, Minos y Radamantis, y uno de Europa, Éaco. Éstos, después de que los hombres hayan muerto, celebrarán los juicios en la pradera en la encrucijada de la que parten los dos caminos que conducen el uno a las Islas de los Bienaventurados y el otro al Tártaro. A los de Asia les juzgará Radamantis, a los de Europa, Éaco; a Minos le daré la misión de pronunciar la sentencia definitiva cuando los otros dos tengan duda, a fin de que sea lo más justo posible el juicio sobre el camino que han de seguir los hombres". (Pl. Grg. 524a; Traducción de J. Calonge). En otro texto, Platón intro- 
lugar del eterno suplicio. Nike, Dike y las Erinias ejecutarán sus decisiones, ratificadas en última instancia por los dioses del Inframundo, y vigilarán su cumplimiento.

Las imágenes de los Infiernos recogen otras figuras que habitan o visitan el Hades. El personaje más recurrente, junto con Orfeo, es Heracles, siempre representado en el acto de tirar esforzadamente de la cadena que sujeta a Cerbero mientras le amenaza con la clava. Es natural que aparezca así pues la razón de su catábasis es apresar a Cerbero para cumplir con uno de los trabajos impuestos por Euristeo. No se representa en estas imágenes cómo libera a Teseo, aunque se alude a ello en la cratera de Armento, al situar la figura del héroe ateniense junto a Heracles, quien dirige su mirada hacia el joven, mientras Hermes abre la marcha del retorno. La presencia de Heracles en el Hades tiene un valor ejemplar y paradigmático: él es el héroe esforzado que, a través del sufrimiento, de las penalidades y de su piedad hacia los dioses, logró triunfar sobre la muerte y alcanzar la inmortalidad. Es instrumento de la divinidad para alentar a los mortales a encontrar, mediante el esfuerzo y la superación, el camino de la sabiduría, de la íntima disolución en la muerte y la liberación final en el renacimiento como inmortal.

Junto con Heracles, el grupo más frecuente es el de los Heráclidas, presente en las crateras de Karlsruhe, Nápoles, Munich (Fig. 7), Malibú, Kiel y Bari. Las figuras representan a dos de los hijos de Heracles y a su madre Megara en amigable conversación y beatífico reposo. Normalmente Megara está sentada, mientras al menos uno de los hijos se mantiene de pie. Ambos jóvenes están representados en desnudez heroica, en actitudes relajadas, apoyando el brazo en su hermano o en su madre. En la mayoría de las imágenes ambos, o uno de ellos, llevan vendas en la cabeza, en torno al pecho o los muslos, alusión a su violenta muerte. Sostienen lanzas, ramas, bastón, fíales, y en la cratera de Munich un aríbalo y una estrígile. ¿A qué se debe la utilización de la imagen de los Heráclidas en el Más Allá? Evidentemente no están relacionados con la figura de su padre, ni con Orfeo, con quien no guardan ninguna relación mítica ni espacial. Su presencia se ha interpretado ${ }^{46}$ como alusión a aquellos inocentes que han muerto violentamente, de ahí las vendas que cubren sus heridas, como ejemplos míticos de mors inmatura. Son también imágenes heroizadas de jóvenes que han muerto en la flor de la vida y preservaron su juventud en el allende.

Teseo y Piritoo son personajes asiduos en las escenas de los Infiernos ${ }^{47}$ debido a su "ilícita" catábasis. En la cratera de Karlsruhe y en la de Munich están representados uno junto a otro, en la zona superior de la escena, uno sentado y el otro de pie, aludiendo a su diferente destino, pues Teseo fue liberado, mientras Piritoo tuvo que permanecer para siempre en el Hades sentado en una roca o asiento del que no podía levantarse. Es con ocasión de la catábasis de Heracles cuando se produce la remisión de la pena de $\mathrm{Teseo}^{48}$, escapando así de una cautividad eterna. Los pintores no hacen una alusión explícita a esa liberación, excepto en la cratera de Armento, donde el joven héroe no figura junto a su amigo Piritoo, que permanece atado a su destino infernal y custodiado por Dike, sino en el registro inferior de la escena, en su extre-

duce a Triptolemo entre los jueces infernales: Pl. Ap. 41a. Minos no está nombrado en ningún vaso con escena de los Infiernos.

46 Schmidt 1988, 727-728.

47 Ambos figuran en otros vasos con representaciones de los Infiernos en los que no figura Orfeo, y que aquí no hemos recogido. Cfr. Pensa 1977, 52 y Moret 1993, 335 ss.

48 Eur., Her., 619, 1169-1170, 1221-1222, 1415; Eur., Heracl., 218-219; Diod., IV 63, 4; Apollod., BibI., II 5, 12 y Epit., I 24; Paus., I 17, 4; Aelian., V.H., IV 5; Hor., Od., IV 7, 27-28; Sen., HF, 806. 


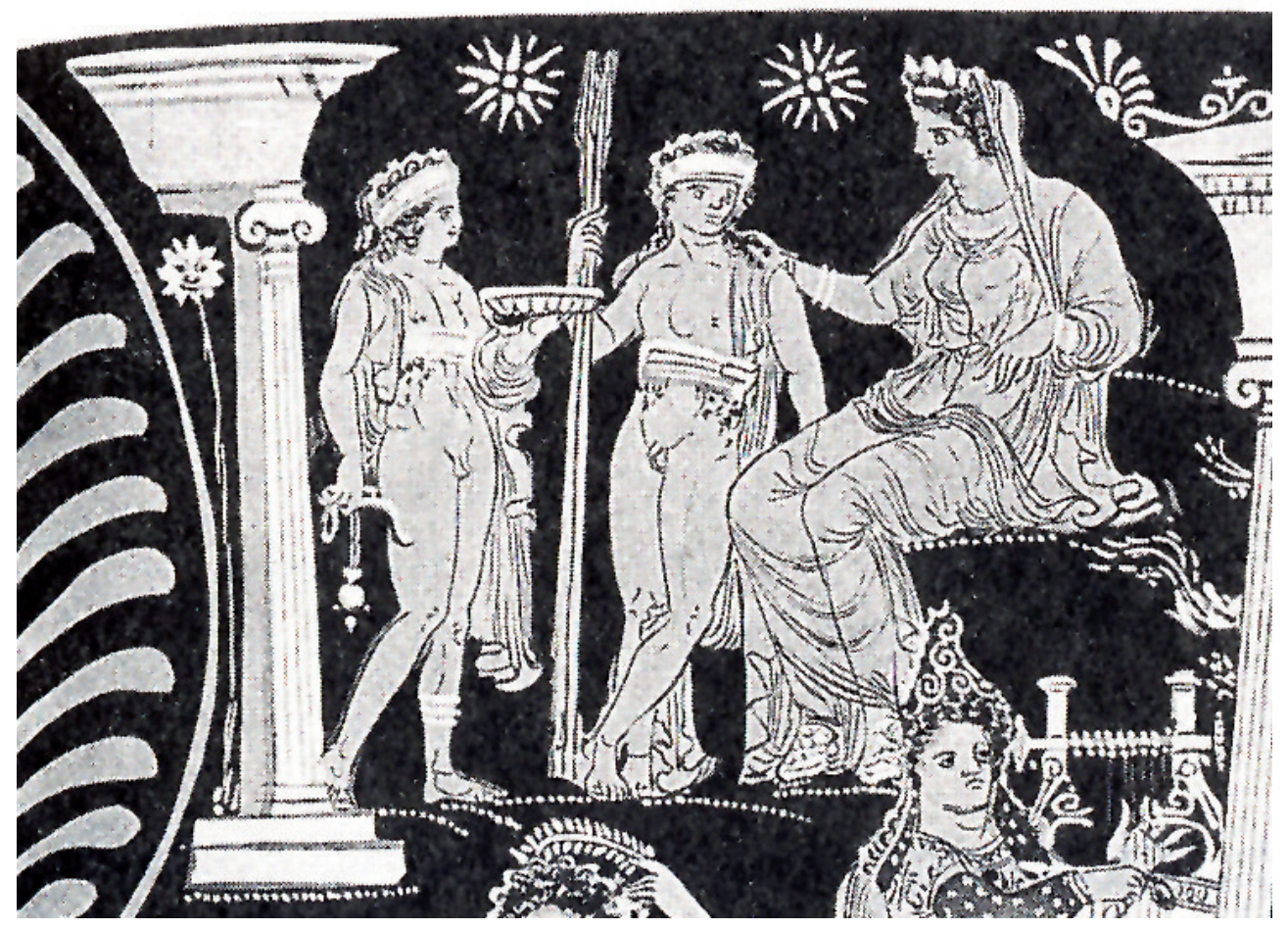

Figura 7. Los Heráclidas en la cratera de Munich (Schmidt 2000, Abb. 1).

mo izquierdo, abandonando ya el reino subterráneo. Hermes le sigue, permitiendo su salida y atestiguando la aquiescencia de los dioses infernales ante su retorno a la vida. Ambos vuelven su cabeza para contemplar la magnífica hazaña de Heracles, quien se debate contra el perro monstruoso mientras gira su rostro para constatar la partida de Teseo, que ya marcha presuroso.

Más enigmática es la presencia del grupo de Pélope, Mirtilo e Hipodamía en la cratera de Nápoles, en la zona superior, a la derecha del palacio infernal, identificados por inscripciones. Algunos autores advierten que esta cratera está muy restaurada y que las inscripciones pudieron ser obra del restaurador ${ }^{49}$. La presencia en el mismo vaso, junto a Heracles y Cerbero, de una Nereida cabalgando un hipocampo, motivo que no tiene ninguna explicación mítica en el Hades, parece confirmar la acción falsificadora y la inventiva del restaurador. Si realmente fueran estas las figuras presentes en el Hades, ¿cómo explicarlas? Quizás por alusión al crimen cometido por Pélope e Hipodamía, y por el propio Mirtilo, los tres culpables de engaño y violencia, aunque aquí no sufren ningún castigo por ello. Quizás sea una alusión al destino trágico de los descendientes de Tántalo, condenado en los Infiernos, cuya

49 Esta era la opinión de Carl Robert, según la recoge Keuls 1974, 92, n. 33, quien suponía que en esta zona del vaso podría haberse representado a Teseo y Piritoo, o Piritoo con Dike; Aellen 1994, 202, $\mathrm{n}^{\circ} 2$, indica que las inscripciones de este grupo son modernas. Pipili $1990,436, n^{\circ} 9$, recoge este grupo en el conjunto de las imágenes que ilustran el episodio del soborno de Mirtilo. 
soberbia desató en las generaciones siguientes nuevos pecados de hybris y terribles violencias.

Tántalo, Sísifo, Ixión y las Danaides son los míticos condenados presentes en estas imágenes de los Infiernos ${ }^{50}$. El primero solo es representado en la cratera de Munich (Fig. 1). Ataviado como un personaje oriental, puesto que era rey de Frigia, con túnica bordada de largas mangas, barbado y cubierto con gorro frigio, está situado en la zona inferior derecha de la escena, bajo una forma ondulada que representa una roca colgante. El pintor no ha escogido la versión homérica del mito (Hom. Od. XI 593-4), que también recogía Platón en Axíoco, 371e, en la que el suplicio consistía en hambre y sed eternas, sino otra versión en la que el castigo era la amenaza infinita de la roca, siempre a punto de caer, siempre en eterno equilibrio ${ }^{51}$. El segundo, Sísifo, figura en las crateras de Karlsruhe, Nápoles y Munich (Fig. 8), y siempre en la misma acción que ya describió Homero: empujando eternamente una gran roca hasta lo alto de una pendiente desde donde volverá a caer. En las crateras de Nápoles y Munich una Furia vigila atentamente su tarea, o incluso le azota mientras la cumple; en la de Karlsruhe las Erinias, situadas justo sobre él, no parecen atentas al condenado, sino a su propia conversación o a la música de Orfeo.

Las Danaides, las cincuenta hijas de Dánao que en la noche de bodas asesinaron a sus esposos, los hijos de Egipto, forman un colectivo representado por tres o a lo sumo cuatro figuras femeninas con hidrias en sus manos ${ }^{52}$. Fue en la Lesche de los Cnidios $^{53}$ donde por primera vez se representó el castigo que sufrieron en el Hades, pero, como ocurriera con la catábasis de Orfeo, los pintores áticos no tuvieron ningún interés en repetir esta historia. Fueron los pintores apulios quienes la pusieron en escena, conformando con este grupo de mujeres otro de los elementos que dibujan el paisaje y la escatología del Hades.

Aunque ninguna inscripción las identifica en las imágenes apulias, el vaso con el que deben cumplir su condena, la hidria, es símbolo escueto que resume varios conceptos y momentos: es el vaso con el que debieron celebrar el rito del baño nupcial, y es precisamente el vaso con el que deben rellenar eternamente una tinaja sin fondo, condenadas así a cumplir una tarea-recoger y transportar agua- que fue desvirtuada y mancillada en el ritual de sus bodas, a reiterar por siempre un ritual ligado a la fertilidad y el matrimonio, no cumplido en vida. Excepto en el ánfora de Tarento, donde figura en el registro inferior una gran tinaja y dos Danaides vertiendo el agua en su interior mientras otra se acerca con la hidria llena y otra se aleja, ningún otro vaso las muestra cumpliendo su inútil tarea ${ }^{54}$ : en las crateras de Karlsruhe y Nápoles están de pie o sentadas, inactivas, con las hidrias en la mano, contemplando lo que sucede en el centro de la escena, quizás ellas también, como las Furias o Cerbero del fragmento de la colección Fenicia, subyugadas por el canto de Orfeo, un canto que ha sido capaz de inmovilizar en su tarea habitual a todos los habitantes del Hades. En las crateras de Malibú, Kiel y Bari, las Danaides, esta vez apoyadas en sus hidrias, están sentadas bajo el palacio infernal y sostienen en sus manos cajas, alabastrones,

50 Ixión, aunque su castigo no tiene lugar en el Hades hasta muy tardíamente, figura en otros vasos con escenas infernales, pero en los que no participa Orfeo (Pensa 1977, 36), por lo que aquí no lo hemos recogido.

51 Pind. Ol. I 57; Pl. Cra. 395d y Apollod. Bibl., II 1.

52 En contra de esta interpretación: Keuls 1974, 45, donde señala que ninguna inscripción en los vasos apulios permite asociar a estas hidróforas con las Danaides.

53 Cfr. n. 4.

54 Pensa $1977,39$. 


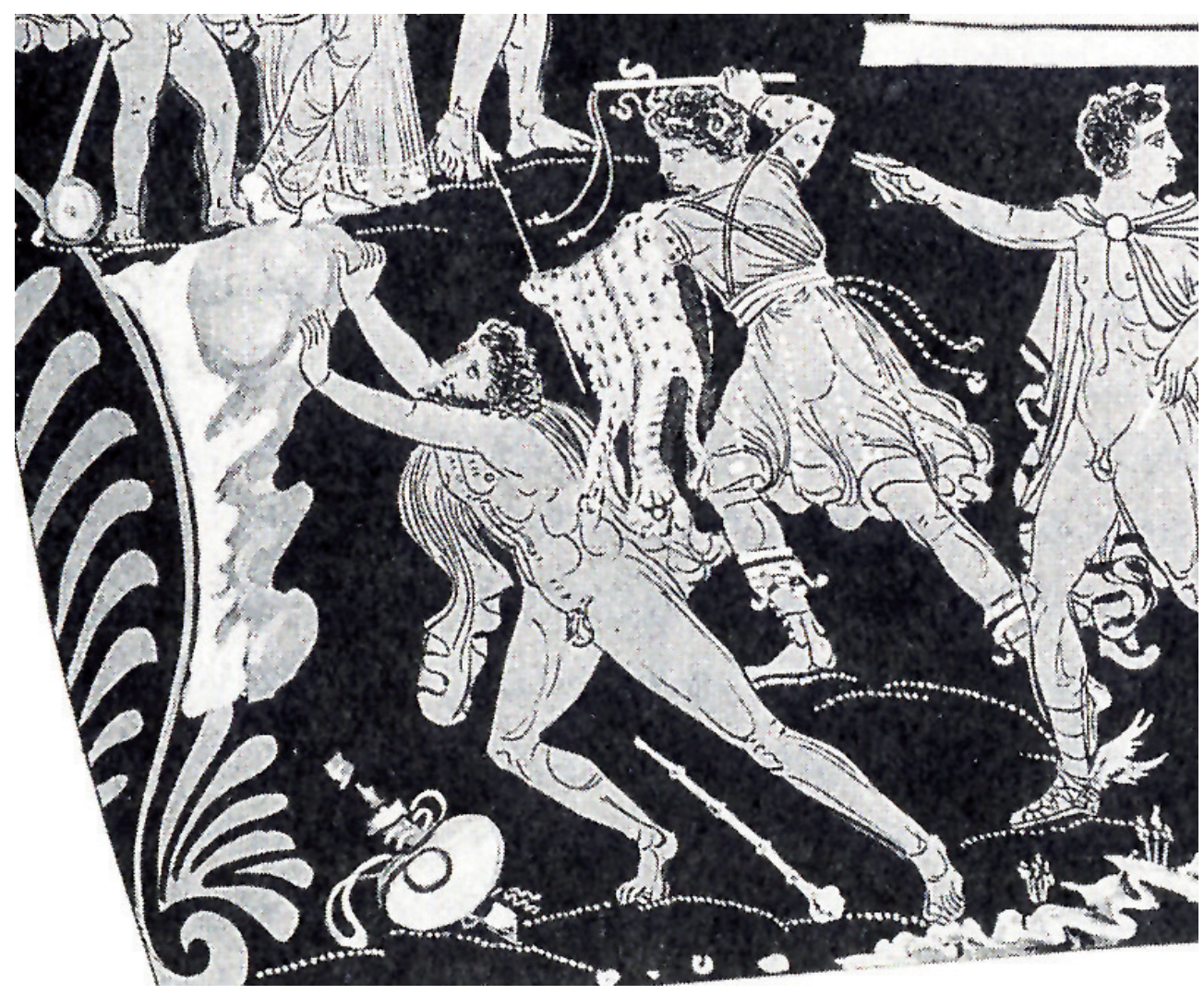

Figura 8. Sísifo y una Furia en la cratera de Munich (Schmidt 2000, Abb. 1).

abanicos y bandejas de frutos, abandonando su tarea ${ }^{55}$ y componiendo un grupo que recuerda más a una escena de boda o de preparación de la novia que a una imagen infernal y a la naturaleza de su categoría como condenadas eternas en el Hades ${ }^{56}$. Estas imágenes dejan traslucir el estado de las Danaides como perpetuamente prenupcial, es decir, incumplido y eternamente estéril ${ }^{57}$. Son así anuncio de la desventura y la infelicidad de los no iniciados, de los que no cumplieron el ritual ni asumieron las normas de vida que éste les indicaba para alcanzar la salvación futura ${ }^{58}$. Las Danaides, ágamos, simbolizarían así el destino de los no iniciados.

55 En la cratera de Kiel la hidria parece llenarse milagrosamente sola bajo el chorro que brota del manantial situado junto a las Danaides. Cfr. Moret 1993, 346.

56 Keuls 1974, 94 aduce, en base a estas últimas imágenes, que las hidróforas no muestran en absoluto un estado de sufrimiento. Pensa 1977, 40, n. 124, propone que otras imágenes de mujeres rellenando con su hidria una gran tinaja y sin ningún otro elemento que las conecte con los Infiernos, no presentan a las Danaides penitentes, sino a las Danaides bienhechoras, dispensadoras del agua en la árida tierra de Argos.

57 Las Danaides representarían el estado ágamos = áteles, no iniciado, frente al estado del matrimonio = iniciado. Cfr. Pensa 1977, 45.

58 Platón habla precisamente de esa "desdicha" de los no iniciados y del destino que les espera en el Hades: "A esa parte del alma, hablando en alegoría y haciendo un juego de palabras, cierto hombre ingenioso, quizá de Sicilia o de Italia, la llamó tonel, a causa de su docilidad y obediencia, y a los insensatos los llamó no iniciados; decía que aquella parte del alma de los insensatos en que se hallan las pasiones, fijando la atención en lo irreprimido 
Se ha propuesto que los pintores apulios habrían representado a las Danaides como bienaventuradas, liberadas de su condena después de haber expiado su crimen por la catarsis de la hidroforia ${ }^{59}$. O que, precisamente por ellas, las imágenes del Inframundo presentan la progresiva purificación de los muertos como modo de transición entre el castigo de los malvados y la beatitud de los puros ${ }^{60}$. Incluso se ha llegado a decir que las Danaides apulias, como las Hespérides, constituyen "an Elysean and not an infernal motif" ${ }^{\prime \prime}$. Sin embargo, esta opinión no se sustenta en las imágenes, pues ninguna de ellas muestra su abandono del Hades ni su presencia en otros contextos paradisíacos. Hermes, que suele cumplir el papel de acompañante o guía de aquellos que abandonan los Infiernos - Teseo, Protesilao, Heracles-, nunca se representa junto a ellas. Y cuando se las representa abandonando su tarea, este abandono puede ser momentáneo, producido por el milagroso canto de Orfeo, que detiene el tiempo y la acción en el Inframundo. Las imágenes muestran que las Danaides no han dejado nunca de ser las criminales condenadas a un suplicio eterno ${ }^{62}$. Orfeo, Teseo, Heracles, Protesilao, Adonis, abandonarán en vida el Hades; ellas, una vez cerradas las puertas del Hades, volverán a su inútil y eterna tarea.

Y por último, entre los visitantes del Hades, un grupo especial solo constatado en la cratera de Munich (Fig. 9), constituido por tres figuras: un varón desnudo de largos cabellos, una mujer y un niño. Los tres caminan juntos, enlazados, tras Orfeo, acercándose al palacio infernal. El varón está coronándose con una corona vegetal y pasa su brazo derecho por detrás de la mujer mientras cruzan sus miradas; ella recoge un extremo del velo y agarra de la mano al niño, quien se vuelve a mirar el juguete que lleva en la otra mano. ¿Quiénes son estos personajes? Lo que es evidente es que componen un grupo familiar, pero ningún otro elemento nos permite identificarlos con un grupo mítico. Aunque Moret $^{63}$ insiste en que es extraño a Orfeo y que habría que buscar su identificación en la esfera del mito, otros autores ${ }^{64}$ ven en ellos a una familia de iniciados que entran en el reino de los muertos guiados por Orfeo. Estos personajes, mortales anónimos, han traspasado las puertas del Hades para llegar ante la presencia de los dioses de ultratumba que decidirán su destino, tal y como indica toda la puesta en escena de la imagen, con sus jueces, démones y personificaciones, condenados y bienaventurados. En este tránsito son guiados por Orfeo, modelo ejemplar de catábasis salvíficas, y por él presentados ante Plutón y Perséfone. Con este grupo familiar de iniciados - en los misterios órficos o dionisía$\cos$, o en cualquier otra religión salvífica- el pintor ha querido ofrecer una imagen más próxima (¿es posible que la familia representada aludiera a la del comitente del vaso?) de esperanza para los mortales y subrayar el papel mediador de Orfeo. El cantor tracio era la figura más adecuada para conducir este tránsito y obtener para los mortales, iniciados o no específicamente en sus misterios, la bendición de los

\footnotetext{
y descubierto de ella, era como un tonel agujereado aludiendo a su carácter insaciable. Éste, Calicles, al contrario que tú, expresa la opinión de que en el Hades -se refiere a lo invisible- tendrían el colmo de la desgracia los no iniciados y llevarían agua al tonel agujereado con un cedazo igualmente agujereado..." (Pl. Grg. 492e-493c; Traducción J. Calonge).

59 Keuls 1974, 86; Schmidt 1975, 123; Schmidt, Trendall y Cambitoglou 1976, 76; Keuls 1986, 341.

60 Schmidt 1975,128

61 Keuls 1974, 101.

62 Es la opinión más generalizada desde Rohde; Cfr. Schauenburg 1958, 50; Nilsson 1967, 825; Moret 1993, 343. De hecho, no se conserva en ninguna fuente literaria en la que las Danaides fueran perdonadas de su condena.

63 Moret 1993, 322.

64 Keuls 1974, 89; Pensa 1977, 45; Schdmit 1975, 32; Bernabé 2009, 113.
} 


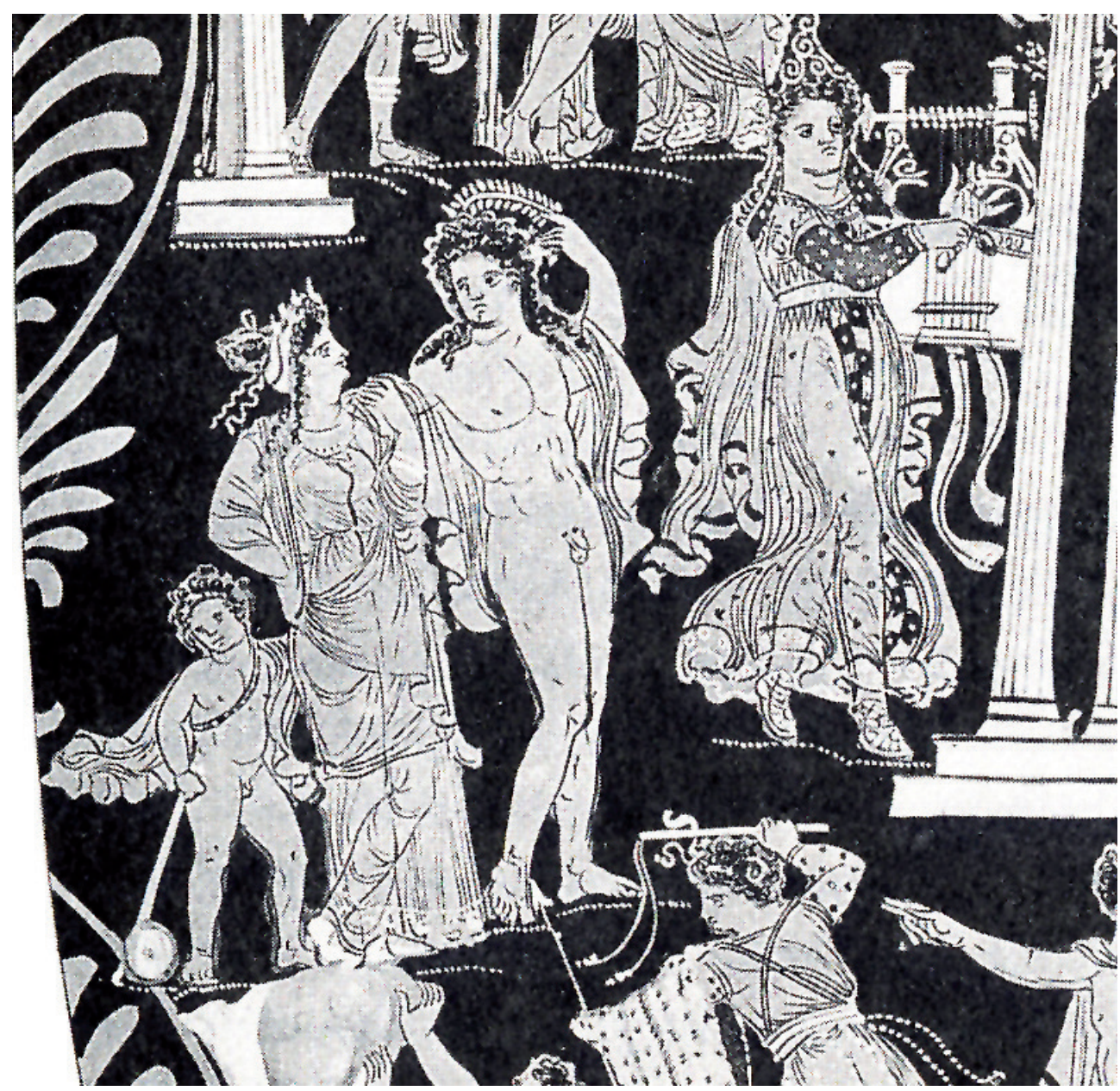

Figura 9. Grupo familiar y Orfeo en la cratera de Munich (Schmidt 2000, Abb. 1).

dioses infernales y la promesa de un estado beatífico en el paradisíaco "recinto de los piadosos". Lo novedoso, e importante, de la escena de la cratera de Munich es precisamente la presencia en el Hades de personajes no míticos, de figuras anónimas, que pueden representar, con una cercanía mucho mayor que la de cualquier personaje mítico, a todos aquellos que creen en una vida eterna y bienaventurada más allá de la muerte, y que ofrecen una esperanza gráfica y directa de triunfo y recompensa. Así lo indican la imagen idealizada de las tres figuras y especialmente la desnudez heroica del varón.

\section{La catábasis de Orfeo}

¿Por qué descendió Orfeo a los Infiernos? La respuesta inmediata nos la proporciona la tradición mítica: para buscar a su esposa fallecida - de la que sabemos su nombre, 
Euridice, por fuentes literarias tardías ${ }^{65}$ - y traerla de nuevo al mundo de los vivos. Sin embargo, este móvil sigue siendo, tras años de polémica, controvertido.

El único documento iconográfico que podría atestiguar esta razón de la catábasis de Orfeo es la cratera de Armento. En ella, en el registro superior, Orfeo, con la cítara en la mano, sujeta a una mujer por la muñeca (cheir epi carpo), quien levanta su velo realizando el gesto de desvelamiento (anakalypstein), gestos que son propios del ritual nupcial, mientras Eros se abraza al cuello del poeta tracio, lo que podría ser un signo de su amor recompensado. Ninguna inscripción nos indica el nombre de la mujer, por lo que podríamos plantearnos si se trata de su esposa o, como sugiere Bernabé $^{66}$, de una difunta, presentada por Orfeo ante los dioses infernales. Parece como si se hubiera querido representar el breve instante en el que Perséfone cede al canto de Orfeo y permite, con un signo de su mano, el reencuentro de los esposos y la partida de Euridice. El mismo Orfeo mantiene la mirada todavía fija en la diosa, la mano izquierda aún sobre las cuerdas de su lira. Pero no sabemos si ambas figuras están llegando o abandonando el Hades. Los gestos y actitud de la mujer como novia podrían aludir a su papel mítico como esposa de Orfeo o a la inmediata boda de la difunta con Hades. En todo caso, no son opciones excluyentes: ya sea Euridice o una mujer mortal anónima, quien se enterró con este vaso podría ver en la figura mítica la encarnación de todos los mortales que, por intermediación de Orfeo, lograron triunfar sobre la muerte.

El anonimato textual e iconográfico de la esposa de Orfeo es muy significativo. De hecho, su relación con Euridice ocupó un lugar muy reducido en el conjunto de los relatos míticos relativos a Orfeo anteriores a la época helenística. Las noticias más antiguas sobre el descenso de Orfeo a los Infiernos no aluden directamente a la esposa del poeta ${ }^{67}$. El Orfeo arcaico es ágamos, su canto no es un canto de amor, sino un canto sagrado que narra el origen del mundo y de los dioses ${ }^{68}$. No es hasta la $\mathrm{Al}$ cestis de Eurípides (vv. 357-362) cuando encontramos la primera referencia literaria a este episodio y la primera alusión al motivo de su catábasis. La idea de que el descenso al Hades tenía por objeto rescatar a Euridice quizás se inspiró en la catábasis de Dioniso, cuando el dios bajó a los Infiernos a buscar a su madre, Sémele, para

65 Heurgon 1932; Macías Otero 2008, 44s. En la literatura la esposa de Orfeo no es llamada Eurídice hasta el periodo helenístico. La primera vez que encontramos su nombre es en Hermesianacte de Colofón (Fr. 7 Powell), ca. 300 a. C., quien la llama Agríope. El nombre de Eurídice aparece por primera vez aplicado a la esposa de Orfeo en el Lamento por Bión del siglo II a.C. (Ps-Moschus en Bio. 3. 124). Se ha argumentado que este nombre aparecía ya en un relieve ático perdido, probablemente de finales del s. V, en el que aparecen tres personajes: Hermes, Orfeo y su esposa. Junto a ella se encuentra inscrito EURUDIKH, pero parece que podría ser un añadido posterior que no habría estado en el original ático (Olmos 2008a, 171). En un fragmento de una cratera de volutas apulia de Karlsruhe (Moret 1993, fig. 7 a), aparecen de manera fragmentaria dos cabezas, una femenina con la inscripción EURUDIKH, y la otra masculina con la inscripción AIWN. Se creyó (Heurgon 1932, 24, ${ }^{\circ}$ 3; Moret 1993, 319) que a esta cratera pertenecía también otro fragmento en el que aparece Orfeo y Perséfone. Hoy en día se ha desechado la unión de ambos fragmentos y se ha propuesto una nueva lectura para el primero como una representación de una escena de Antígona, en la que se encontraría Eurídice, la esposa de Creonte, quizá acompañada de Hemón o Alcmeón (Krauskopf 1981, nº 16).

66 Bernabé 2009, 114-115, n. 55.

67 Macías Otero 2008, 539: "hay noticias y algún fragmento (OFF 707-710, un fragmento OF 711.) de una Catábasis de Orfeo. Sobre el modelo de la Nekya de la Odisea, se habría producido un poema atribuido a Orfeo, en el que en primera persona se narraría lo que el bardo tracio contempló en su descenso al Hades. Aunque se desconoce la fecha de composición de esta obra, es probable que fuera bastante antigua, pues parece que su influencia puede detectarse en las Basárides de Esquilo".

68 Heurgon 1932, 7. 
llevarla junto a él al Olimpo ${ }^{69}$. Esta figura mitológica, por tanto, no tiene personalidad propia, no cumple otra función que la de ser el motivo de la catábasis de Orfeo y de su triunfo sobre la muerte. Euridice no existe más que en función del tránsito del poeta tracio, no comienza a vivir más que en el instante de su muerte ${ }^{70}$.

Pero si el motivo era, en la argumentación mítica, evidente, ni los textos ni las imágenes insisten en ello. Porque lo importante no era rescatar a Euridice, sino la catábasis en sí misma, una catábasis triunfal, pues Orfeo es capaz de penetrar con vida en el reino de los muertos, seducir con su canto a los dioses infernales y con vida salir del Hades, con o sin su esposa ${ }^{71}$. Si logró o no devolver a la vida a Euridice es solo un problema en el relato mítico, pero no en la concepción escatológica de la función de Orfeo en su descenso a los Infiernos.

El tránsito de Orfeo, y es en lo que las imágenes apulias insisten, es un hecho esencial, pues permitió que el poeta conociera la geografía infernal y contemplara todo lo que sucede en el Hades, todo lo que concierne al destino de las almas más allá de la muerte, y que pudiera trasmitirlo a los vivos. Pero no solo eso: Orfeo logró con su canto conmover a los dioses de tal manera que accedieron a quebrantar la ley natural y permitir que la esposa muerta -el gesto liberador de Perséfone en la cratera de Armento es muy significativo al respecto- volviera a la vida, logró que los dioses abrieran para los mortales la puerta que conduce a un destino beatífico y paradisíaco. En este sentido, Orfeo no es solo el protagonista de un relato mítico sino una figura religiosa que intercede ante los dioses del inframundo para obtener de ellos la salvación de los mortales en su destino ultraterreno.

\section{Conclusiones}

Los vasos monumentales apulios con escenas del descenso de Orfeo a los Infiernos nos han mostrado todo un microcosmos de alto contenido simbólico y escatológico. Los pintores conciben el reino subterráneo como un paisaje sintético, construido con elementos arquitectónicos y naturales y, sobre todo, por personajes cuyo ámbito es obligatoriamente el Hades. Está presidido por el palacio de Plutón y Perséfone, representado como un templete blanco, cubierto por un tejado a dos aguas rematado en un frontón triangular, sostenido por cuatro columnas jónicas. En algún caso también figura la puerta del Hades, una puerta que abre Nike al camino de retorno para aquellos privilegiados que penetraron vivos en el Hades y vivos salen de él, pero que también puede abrir para aquellos que han recibido el premio de una vida bienaventurada en un ámbito paradisíaco. Alrededor del palacio de los dioses infernales se dibujan entornos diferentes: por un lado, el recinto de los piadosos, ese espacio paradisíaco, lugar de esparcimiento y ejercicio, señalado por la fuente y la columna de la palestra junto a la que se sitúan los Heráclidas; por otro lado, la morada de los impíos, los abruptos y rocosos paisajes donde los condenados cumplen su castigo. Y

\footnotetext{
Heurgon 1932, 9. La comparación del móvil de Orfeo con el de Dioniso ya la realizó Diodoro, IV, 23.

Heurgon 1932, 15.

71 Sobre el "final feliz" de la historia de Orfeo y Euridice cfr. Macías Otero 2008, 47-65, con bibliografía anterior. Según Macías, no existe ningún testimonio que apoye de manera sólida esa versión, pues todos se interrumpen en el momento en que los dioses infernales acceden a la petición de Orfeo de que le permitan intentar devolver a su esposa al mundo de los vivos, y no contienen ninguna referencia clara a lo que pudo haber sucedido después.
} 
un espacio, diferenciado de los anteriores, donde los jueces del inframundo juzgan a las almas y deciden su destino.

Orfeo es el visitante privilegiado de los Infiernos, y es, junto con Plutón y Perséfone, la figura principal de estas imágenes del Inframundo. Los pintores le representan vestido al modo oriental, tañendo las cuerdas de la cítara, danzando y cantando al mismo tiempo, o estático, esperando atento el resultado de su canto. Plutón y Perséfone son figuras indispensables en este imaginario del Hades, pues representan el universo divino que rige los destinos ultraterrenos de los mortales y sintetizan con su sola figura el espacio, la geografía y la teología del Más Allá. La pareja atiende la llegada de Orfeo, ambos escuchan ensimismados el canto y la música seductores del poeta tracio. Hécate es otra figura habitual en estas imágenes, pues, provista de antorchas, ilumina las tinieblas del Hades y guía a los que se adentran en este tenebroso espacio, a aquellos personajes excepcionales que han penetrado vivos en el reino infernal y que, por ello, no permanecerán allí definitivamente. Su papel como diosa de los Infiernos es fundamental pues, al igual que Hermes, pone en comunicación dos ámbitos existenciales radicalmente alejados y distintos. El dios también cumple en estas imágenes la función de guía, de conductor de los héroes de vuelta al mundo de los vivos.

Otras divinidades y démones pueblan el Inframundo. Actúan como asistentes de los dioses infernales y como garantes de la aplicación de sus designios. Así, las Furias o Erinias, quienes ejecutan los castigos impuestos a los condenados, y Dike, la Justicia, representada con una espada en la mano. Ambas figuras encarnan un concepto trascendental: el orden cósmico regido y sancionado por los dioses que regula el equilibrio entre el bien y el mal, que premia y castiga, y que ofrece la esperanza de una vida equitativa tras la muerte. Un papel trascendental cumplen también los Jueces infernales, representados en algunos de estos vasos, quienes juzgarán a las almas y decidirán su destino: hacia el paraíso beatífico de los bienaventurados, o hacia el lugar del eterno suplicio. Nike, Dike y las Erinias ejecutarán sus decisiones, ratificadas en última instancia por los dioses del Inframundo, y vigilarán su cumplimiento.

Entre los visitantes del Hades, el héroe recurrente es Heracles, siempre representado en el acto de tirar de la cadena que sujeta a Cerbero mientras le amenaza con la clava. Su presencia en el Hades tiene un valor ejemplar y paradigmático: él es el héroe esforzado que, a través del sufrimiento, de las penalidades y de su piedad hacia los dioses, logró triunfar sobre la muerte y alcanzar la inmortalidad. Teseo y Piritoo también son personajes asiduos en las escenas de los Infiernos, representados uno junto a otro, uno sentado y el otro de pie, aludiendo a su diferente destino. Los pintores no hacen una alusión explícita a la liberación de Teseo por Heracles, excepto en uno de los vasos, donde el héroe ateniense abandona ya el reino subterráneo. Junto con Heracles, el grupo más frecuente es el de los Heráclidas, dos de los hijos del héroe y su madre Megara. En la mayoría de las imágenes ambos, o uno de ellos, llevan vendas en la cabeza, en torno al pecho o los muslos, alusión a su violenta muerte. Funcionan como alusión a aquellos inocentes que han muerto violentamente, como ejemplos míticos de mors inmatura, y son figuras heroizadas que pueden aludir al estado de beatífico reposo y plenitud que los bendecidos alcanzarán en un allende paradisíaco.

Tántalo, Sísifo y las Danaides son los míticos condenados presentes en estas imágenes de los Infiernos. El primero aparece bajo la amenaza infinita de una roca, siempre a punto de caer, siempre en eterno equilibrio; el segundo, empujando eter- 
namente una gran roca hasta lo alto de una pendiente desde donde volverá a caer. Las Danaides figuran siempre con hidrias en las manos, el vaso con el que deben rellenar eternamente una tinaja sin fondo. Las imágenes dejan traslucir su estado como perpetuamente prenupcial, es decir, incumplido y eternamente estéril, condenadas a reiterar por siempre un ritual ligado a la fertilidad y el matrimonio, no cumplido en vida, quizás como anuncio de la desventura y la infelicidad de los no iniciados, de los que no cumplieron el ritual ni asumieron las normas de vida que éste les indicaba para alcanzar la salvación futura.

En conclusión, las imágenes apulias de Orfeo en los Infiernos nos permiten acompañar al poeta en su descenso al Hades, conocer su geografía, atravesar los ríos y corrientes de agua del inframundo, contemplar el palacio de Plutón y Perséfone, llegar hasta la "llanura de la verdad", donde los jueces infernales juzgarán las acciones de los mortales, asistir al castigo eterno de los condenados, de las Danaides rellenando inútilmente la tinaja sin fondo, de Sísifo empujando una roca que siempre vuelve a caer, de Tántalo siempre bajo la amenaza de una roca en perpetuo e inestable equilibrio, ver a las Erinias infligiendo su castigo a los condenados o vigilando para que se cumpla su condena, a Dike presidiendo el establecimiento de la justicia cósmica, a Hermes y Hécate acompañando el tránsito de aquellos que, como Teseo y Heracles, lograron vencer a la muerte y retornar a la vida, a Nike ofreciendo el triunfo para los piadosos, la recompensa de un destino beatífico donde las almas gozarán, como los Heráclidas, de juegos y placeres eternos.

En estas imágenes Orfeo es un mediador, y así se concibe especialmente en la cratera de Munich, donde precede la llegada de una familia anónima, no mítica, ante el palacio de Plutón y Perséfone. ¿Representan estas figuras a los iniciados en los misterios órficos, o, más ampliamente, a todos aquellos que creen en la salvación del alma y en una existencia beatífica más allá de la muerte? Es evidente que los iniciados órficos verían en la figura de Orfeo a su guía y protector, a aquel que ha descendido a los Infiernos para descubrir los secretos de la vida y la muerte y para interceder en favor de sus mistes, a aquel que, a través de sus enseñanzas, trasmitidas en la iniciación, les indicaba la práctica de un modo de vida necesario para obtener la salvación y les mostraba, porque ya estuvo allí, el camino hacia el Hades y lo que allí sucedía. Esto mismo parece reflejar la imagen de un ánfora de Basilea ${ }^{72}$, donde el mítico cantor figura en el interior del naisco que alberga al difunto, un varón sentado que sostiene en sus manos un volumen, posiblemente un texto iniciático funerario, como las laminillas órficas. La coincidencia en el mensaje salvífico de imágenes y textos órficos así lo confirma.

Esta misma función mediadora ofrece Dioniso en las imágenes de los vasos suritálicos, especialmente en la cratera de Toledo, donde el dios estrecha su mano con Hades, estableciendo así un pacto por el que sus seguidores recibirán un tratamiento especial en el Hades y encontrarán descanso a sus fatigas ${ }^{73}$. En ésta y en otras imágenes de los vasos suritálicos el dionisismo se confirma como una religión definitivamente salvífica, pues el mensaje que trasmiten no puede ser más contundente: el dios tiene el poder de ofrecer la vida tras la muerte. Si los textos no ofrecen una visión del dionisismo como una religión que ofrezca la promesa de una vida en el Más Allá, si no existen testimonios literarios de época clásica que, a diferencia de la teo-

LIMC 88; Olmos 2008, 280-283; Bernabé 2009, 117, fig. 6.8.

Johnston y McNiven 1996; Cfr. también Schmidt 2000, 98-99. 
logía órfica, documenten promesas de bienaventuranza para los fieles dionisíacos ni amenaza de castigo a los profanos ${ }^{74}$, las imágenes suritálicas ofrecen un panorama completamente diferente. La iconografía de los vasos así nos lo dice al mostrar los dones ${ }^{75}$ que el dios otorgará en el allende a quien se inicia en sus misterios, en sus ritos y en su culto, pero también, de forma más amplia, a todos aquellos que creen en su poder y que anhelan una existencia plena más allá de la muerte.

No creo, por tanto, que esta función mediadora de ambos personajes, el divino y el humano, fuera exclusiva para con los iniciados en los misterios órficos ${ }^{76}$. Todos aquellos que creyeran en una vida después de la muerte, verían en Orfeo, y especialmente en Dioniso, a entidades religiosas que les ofrecían no solo instrucciones para afrontar el tránsito de la muerte, sino, sobre todo, la esperanza de trascendencia, la promesa de una vida plena y eternamente feliz en el Más Allá.

Estas imágenes insisten en presentar una concepción amplia del Inframundo, un lugar donde reina la justicia, donde los dioses vigilan el cumplimiento de un orden cósmico, donde se juzga a los mortales, se castigan las acciones impías y se recompensa a los piadosos, donde el alma, tras ser juzgada, podrá obtener la recompensa de la inmortalidad, alcanzar una existencia beatífica, una nueva vida gozosa y plena.

\section{Bibliografía}

Aellen, Ch., 1994, À la recherche de l'ordre cosmique. Forme et fonction des personnifications dans la céramique italiote, Akanthus, Zürich.

Bernabé, A., 2009, “Imago Inferorum Orphica”, en G. Casadio, y P.A. Johnston (eds.), Mystic Cults in Magna Graecia, University of Texas Press, 95-130.

Cabrera, P., 1998, "Dioniso en un jardín. El espacio de la iniciación en la iconografía de los vasos apulios", en C. Sánchez y P. Cabrera (eds): En los límites de Dioniso. Actas del Simposio celebrado en el Museo Arqueológico Nacional (Madrid, 20 de junio de 1997), Murcia, 61-87.

Cabrera, P., 2013, “The Gifts of Dionysus”, en A. Bernabé, M. Herrero de Jáuregui, A. I. Jiménez San Cristóbal y R. Martín Hernández (eds.): Redefining Dionysus, De Gruyter, Berlin/Boston 2013, pp. 488-503.

Calame, Cl., 2009, Poetic and Performative Memory in Ancient Greece: Heroic Reference and Ritual Gestures in Time and Space. Hellenic Studies Series 18. Washington, DC: Center for Hellenic Studies. https://chs.harvard.edu/CHS/article/display/5807 [acceso: 18.09.2017].

Garezou, M.X., 1994, “Orpheus”, en Lexicon Iconographicum Mythologiae Classicae vol. VII, Zürich, 81-105.

\footnotetext{
Jiménez San Cristóbal 2008, 726.

Cabrera 2013.
}

76 Schdmit 1975, 137, plantea que las representaciones apulias de ultratumba reflejan una concepción que corresponde a una ideología órfica. Bernabé 2009, 121, se plantea si podemos o no llamar "órfico" a este continuo religioso, informado por los textos y las imágenes, y se pregunta: “¿Qué otro movimiento podemos reconstruir que una a Perséfone y Dioniso con Orfeo como mediador, que recurre a textos sagrados y presenta un Inframundo con la posibilidad de premios y castigos? Parece más plausible creer que los textos que sirvieron de base a los artistas pudieron ser los empleados en las teletai, que podrían incluir representaciones de los sagrados misterios en forma de catábasis en una especia de imitatio mortis, preparando al creyente para la gran experiencia.". Sin embargo, la representación del Inframundo no era exclusiva de textos sagrados relacionados con las teletai, véase por ejemplo las descripciones de Platón y de otros autores. 
Harrison, J.E., 1909, « Dike or Eurydike? », Archiv für Religionswissenschaft 12, 411.

Heurgon, J., 1932, « Orphée et Eurydice avant Virgile », Mélanges d'archéologie et d'histoire, 49, 6-60.

Jiménez San Cristóbal, A. I., 2008, “Orfismo y dionisismo”, en A. Bernabé y F. Casadesús (coord.), Orfeo y la tradición órfica. Un reencuentro. Akal, Madrid, 697-730.

Johnston, S.I. y McNiven, T.J., 1996, "Dionysos and the underworld in Toledo", Museum Helveticum 53, 25-36.

Keuls, E., 1974, The Water Carriers in Hades: a study of catharsis through toil in classical antiquity, Amsterdam.

Keuls, E., 1986, "Danaides", Lexicon Iconographicum Mythologiae Classicae vol. III, Zürich, 337-341.

Krauskopf, I., 1981, “Antigone”, Lexicon Iconographicum Mythologiae Classicae vol. I, Zürich, 818-828.

Macías Otero, S. M., 2008, Orfeo y el orfismo en Eurípides, Universidad Complutense, Madrid.

Moret, J.M., 1993, «Les départs des Enfers dans l'imagerie apulienne », Revue Archéologique, 293-351.

Nilsson, M.P., 1967, Geschichte der griechischen Religion, München.

Olmos, R., 2008a, "Las imágenes de un Orfeo fugitivo y ubicuo", en A. Bernabé y F. Casadesús (coord.), Orfeo y la tradición órfica. Un reencuentro. Akal, Madrid, 137-178.

Olmos, R., 2008b, "Iconographical notes on the orphic tablets", en A. Bernabé y A.I. Jiménez (eds.), Instructions for the neverworld: the Orphic gold tablets, Brill, Leiden, 273-326.

Pensa, M., 1977, Rappresentazioni dell'Oltretomba nella ceramica apula, L'Erma di Bretschneider, Roma.

Pipili, M., 1990, “Hippodameia I", Lexicon Iconographicum Mythologiae Classicae vol. V, Zürich, 434-440.

Schauenburg, K., 1958, “Die Totengötter in der unteritalischen Vasenmalerei”, Jahrbuch des Deutschen Archäologischen Instituts 73, pp. 48-71.

Schauenburg, K., 1984, "Unterweltsbilder aus Grossgiechenland”, Römische Mitteilungen 91, 359-387.

Schmidt, M., 1975, "Orfeo e orfismo nella pittura vascolare italiota", en Orfismo in Magna Grecia. Atti del quattordicesimo convegno di studi sulla Magna Grecia, Taranto (6-10 ottobre 1974), Napoli, 105-137.

Schmidt, M., 1988, “Herakleidai”, en Lexicon Iconographicum Mythologiae Classicae vol. IV, Zürich, 723-728.

Schmidt, M., 1991, "Bemerkungen zu Orpheus in Unterwelts-und Thrakerdarstellung", en Philippe Borgeaud (éd.), Orphisme et Orphée (En l'honneur de Jean Rudhardt), Geneva, 31-50.

Schmidt, M., 2000, “Aufbruch oder Verharren in der Unterwelt?”, Antike Kunst 43, 86-99.

Schmidt, M., Trendall, A.D. y Cambitoglou, A., 1976, Eine Gruppe Apulischer Grabvasen in Basel. Studien zu Gehalt und Form der unteritalischen Sepulkralkunst, Archäologischer Verlag, Bâle.

Stansbury-O’Donnell, M.D., 1990, "Polygnotos's Nekyia: A Reconstruction and Analysis", American Journal of Archaeology 94, 2, 213-235.

Trendall, A.D. y Cambitouglou, A., 1978, The Red-Figured Vases of Apulia, vol. I. Oxford Monographs on Classical Archaeology, Oxford.

Trendall, A.D. y Cambitouglou, A., 1982, The Red-Figured Vases of Apulia, vol. II. Oxford Monographs on Classical Archaeology, Oxford. 
Trendall, A.D. y Cambitoglou, A., 1991-92, Second supplement to the red-figured vases of Apulia, University of London, Institute of Classical Studies, Bulletin supplements 60, London.

Villing, A., 2014, “'Dangerous perfection'. And an old puzzle resolved: a 'new' apulian krater inspired by Euripides' Antiope”, Bulletin of the Institute of Classical Studies 57, 1, 61-78. 
